INTERNATIONAL MONETARY FUND

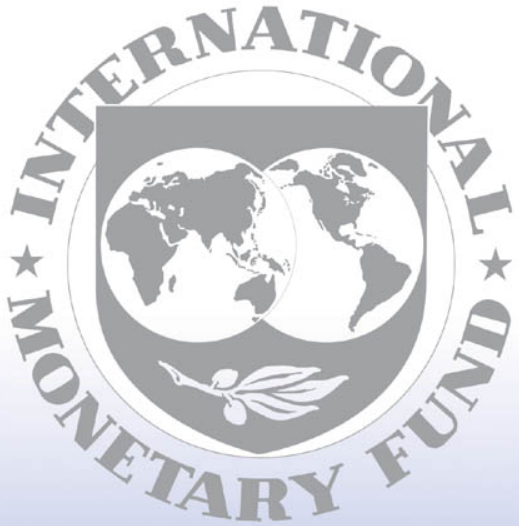

Staff

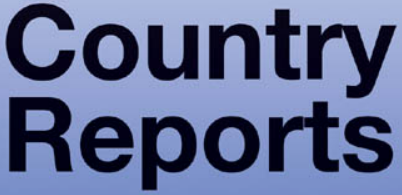




\section{Arab Republic of Egypt: 2007 Article IV Consultation-Staff Report; Staff Statement; Public Information Notice on the Executive Board Discussion; and Statement by the Executive Director for the Arab Republic of Egypt}

Under Article IV of the IMF's Articles of Agreement, the IMF holds bilateral discussions with members, usually every year. In the context of the 2007 Article IV consultation with the Arab Republic of Egypt, the following documents have been released and are included in this package:

- $\quad$ The staff report for the 2007 Article IV consultation, prepared by a staff team of the IMF, following discussions that ended on September 12, 2007, with the officials of the Arab Republic of Egypt on economic developments and policies. Based on information available at the time of these discussions, the staff report was completed on November 1 , 2007. The views expressed in the staff report are those of the staff team and do not necessarily reflect the views of the Executive Board of the IMF.

- $\quad$ A staff statement of November 28, 2007 updating information on recent developments.

- $\quad$ A Public Information Notice (PIN) summarizing the views of the Executive Board as expressed during its November 28, 2007 discussion of the staff report that concluded the Article IV consultation.

- $\quad$ A statement by the Executive Director for the Arab Republic of Egypt.

The document listed below has been or will be separately released.

Selected Issues Paper

The policy of publication of staff reports and other documents allows for the deletion of market-sensitive information.

To assist the IMF in evaluating the publication policy, reader comments are invited and may be sent by e-mail to publicationpolicy@imf.org.

Copies of this report are available to the public from

International Monetary Fund • Publication Services

$70019^{\text {th }}$ Street, N.W. $\bullet$ Washington, D.C. 20431

Telephone: (202) 623-7430 • Telefax: (202) 623-7201

E-mail: publications@imf.org•Internet: http://www.imf.org

Price: $\$ 18.00$ a copy

\section{International Monetary Fund Washington, D.C.}


This page intentionally left blank 
INTERNATIONAL MONETARY FUND

ARAB REPUBLIC OF EGYPT

Staff Report for the 2007 Article IV Consultation

Prepared by the Staff Representatives for the 2007 Consultation with the Arab Republic of Egypt

Approved by Lorenzo Pérez and Carlo Cottarelli

November 1, 2007

- Discussions were held in Cairo August 29-September 12, 2007. The team comprised Mr. Enders (head), Mr. Ilahi, Mr. Billmeier, Ms. Oner (all MCD), Mr. Almekinders (PDR), Ms. Cebotari (FAD) and was supported by Mr. Sassanpour (Senior Resident Representative). Ms. Scarlata (MCM) discussed the findings of the May 2007 FSAP update mission. Mr. Shaalan and Ms. Riad (both OED) participated in the policy discussions.

- The mission met with Ministers Boutros-Ghali (Finance), Mohieldin (Investment), and Osman (Economic Development), Central Bank Governor El-Okdah, and other government officials and private sector representatives. The mission's concluding statement was published (http://www.imf.org/external/np/ms/2007/091207.htm).

- The last Article IV consultation was concluded on July 5, 2006. Directors' comments may be found at http://www.imf.org/external/pubs/cat/longres.cfm?sk=19426.0

- On January 2, 2005, Egypt accepted the obligations under Article VIII, sections 2, 3, and 4 of the Articles of Agreement. The exchange system is free of exchange restrictions on the making of payments and transfers for current international transactions and multiple currency practices.

- The de jure exchange rate regime is a managed float. While through mid-2007 the de facto exchange rate arrangement was akin to a conventional fixed peg, in the last few months it has been akin to a managed float. 


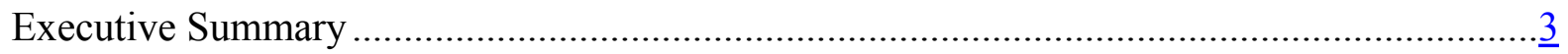

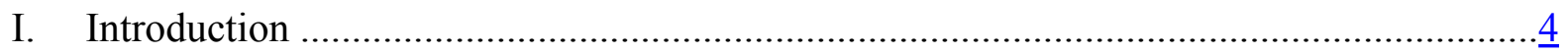

II. Background and Developments ............................................................................ 4

III. Egypt's Medium-Term Policy Framework........................................................... 12

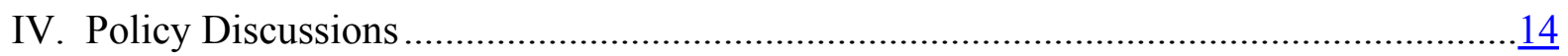

A. Getting the Policy Mix Right..............................................................................

B. Financial Sector Reforms for Growth and Stability ...........................................15

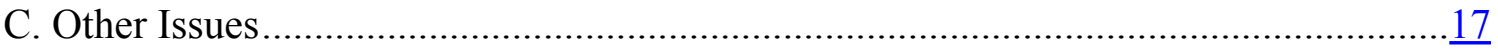

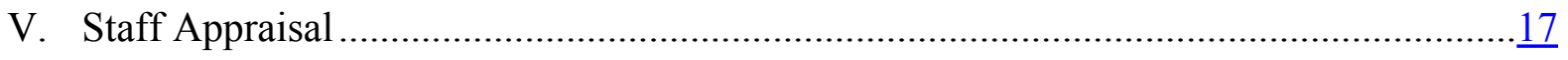

Boxes

1. Inflation Developments ......................................................................................... 11

2. Egypt's Current Account and Equilibrium REER ...................................................13

3. The 2007 Financial Sector Assessment Program (FSAP) Update.................................16

Figures

1. Egypt: Reserve Benchmark Indicators, FY 2000/01-2006/07 …................................20

2. Egypt and Comparator Countries: Reserve Benchmark Indicators, 1999-2007 .............21

3. Egypt: Public Debt Sustainability: Bound Tests ...................................................

4. Egypt: External Debt Sustainability: Bound Tests .................................................

Tables

1. Selected Macroeconomic Indicators, 2003/04-2007/08 ….........................................22

2. Summary of Budget Sector Fiscal Operations............................................................23

3. General Government Fiscal Operations ..................................................................24

4. Medium-Term Macroeconomic Framework, Baseline Scenario, 2003/04-2011/12 .......25

5. Monetary Survey, 2003/04-2011/12 …................................................................. 26

6. Medium-Term Balance of Payments, 2003/04-2011/12 ….......................................

7. Selected Vulnerability Indicators, 2003/04-2007/08 .................................................. $\underline{28}$

8. Public Sector Debt Sustainability Framework, 2002/03-2012/13 _................................29

9. External Debt Sustainability Framework, 2002/03-2012/13 ........................................ 


\section{EXECUTIVE SUMMARY}

\section{Economic Developments}

- Egypt's economy had another year of impressive performance supported by sustained reforms, prudent macroeconomic management, and a favorable external environment. Growth was strong and has become more broad-based, creating record numbers of jobs. Investor confidence remains high.

- Inflation returned to single digits after a temporary surge triggered by supply shocks and administered price adjustments. However, inflationary pressures from strong domestic demand and rising world food prices persist. Actions to contain fuel subsidies, wage restraint, one-off receipts, and better cash management produced the lowest budget deficit in years.

- Structural reforms continued at an impressive pace: the fourth-largest state bank and a large department store were privatized, tax administration was strengthened, and import tariffs were reduced. Procedures for the registration of new businesses and of property, as well as customs clearance, were streamlined.

\section{Policy Issues}

- Economic policies are geared toward sustaining high growth and creating jobs for a rapidly growing labor force. Reforms aim to enhance investment incentives by further improving the business environment, while raising national savings and ensuring domestic and external stability through continued fiscal adjustment.

- The government plans to reduce the fiscal deficit gradually to 3 percent of GDP by $2010 / 11$ to bring public debt on a firmly declining path. This will require a reduction in energy subsidies, containment of the wage bill, overhaul of the sales and property tax regimes, and continued reform of the tax administration. Improvements in public spending efficiency, including on social safety nets, will be equally critical to sustain growth and strengthen the needed consensus for reforms, especially given the disaffection of many groups with the lags in the "trickling down" of the benefits of reform.

- The recent move toward greater exchange rate flexibility needs to continue to better support the conduct of a monetary policy aimed at fighting inflation and achieving short term stabilization, in line with the authorities' choice of a managed float regime. Staff estimates indicate that the current account is consistent with external stability and the exchange rate is broadly in line with fundamentals.

- The authorities' plans for further financial sector reforms are consistent with key recommendations of the FSAP update. Continued effort is needed to improve bank and nonbank supervision, complete the bank recapitalization program, enhance the monitoring of state banks, and undertake complementary regulatory and judicial reforms 


\section{INTRODUCTION}

1. Since last year's Article IV consultation, Egypt's economy has continued to grow briskly, and inflation has moderated after a surge in 2006. While the reformist cabinet continues to press ahead with policy and structural changes, opposition to reform has become more vocal, fuelled in part by high food-price inflation and some frustration about the lag in the "trickle down" of the benefits of growth.

2. Egypt made significant progress on the issues raised in the 2006 consultation. The authorities implemented a sizable fiscal adjustment, strengthened tax administration, further liberalized the trade regime, and privatized financial and nonfinancial enterprises. The exchange rate has become more flexible since July 2007.

3. Discussions centered around achieving a macroeconomic policy mix that would support higher growth and investment by ensuring domestic and external stability. The policies discussed included (i) fiscal adjustment to raise national saving and ensure sustainable public debt dynamics; (ii) greater exchange rate flexibility in line with the authorities' choice of a managed float and the planned move to inflation targeting in an environment of large capital flows; (iii) a monetary policy stance that keeps inflation low while accommodating supply shocks and administered price changes; (iv) and further financial sector reform.

\section{BACKGROUND AND DEVELOPMENTS ${ }^{1}$}

4. The broad-based economic expansion has created many jobs, public finances have improved, and structural reforms have further liberalized the Egyptian economy.

- The economy grew at 7 percent a year. Nonhydrocarbon growth surged from 5.8 percent in 2005/06 to 7.1 percent in 2006/07, broadening to labor-intensive agriculture, manufacturing, services, and construction. The spike in inflation was largely the result of one-off factors, but demand pressures and imported inflation also played a role (Box 1).

- The current growth spurt created about 2.5 million jobs between end-2004 and March 2007, reducing unemployment from 11.8 percent to 9 percent. $^{2}$ Skill mismatches remain a hindrance to job growth, and formal sector employment is hindered by high nonwage labor costs and expensive firing rules.

\footnotetext{
${ }^{1}$ See charts; all data based on official statistics.

${ }^{2}$ Changes in the labor force survey were introduced in late 2006 and may have affected the continuity of the unemployment data series.
} 
Rising and broadening growth...

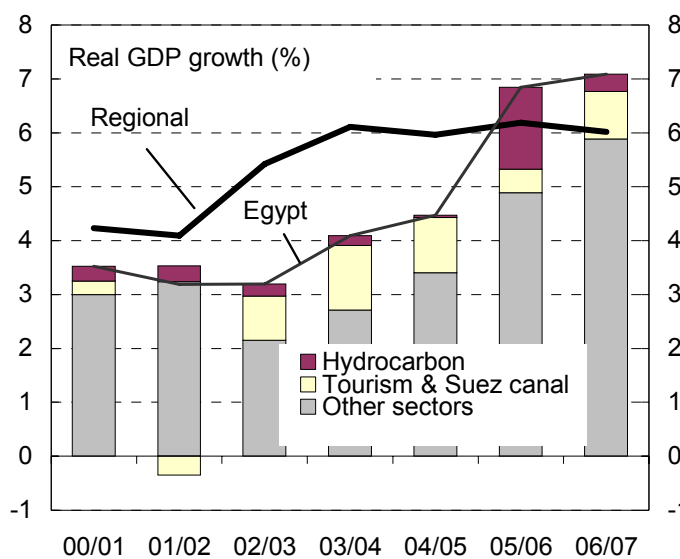

Income has been boosted by the coming on stream of gas fields...

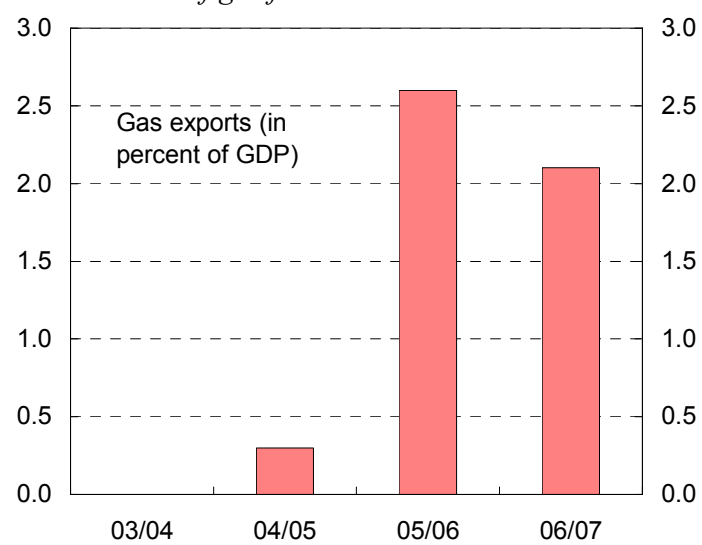

The Egyptian stock market has been one of the best performers in the region, and the index nearly quadrupled over the last three years...

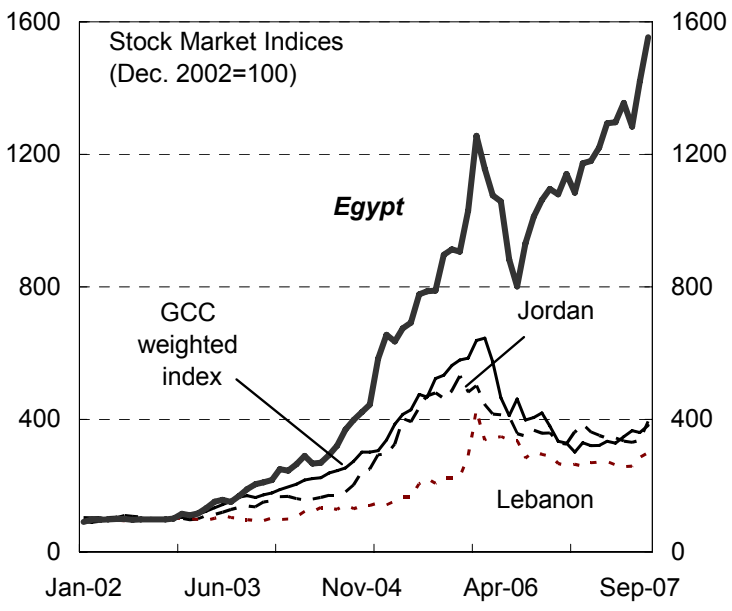

...has started to make a dent in unemployment.

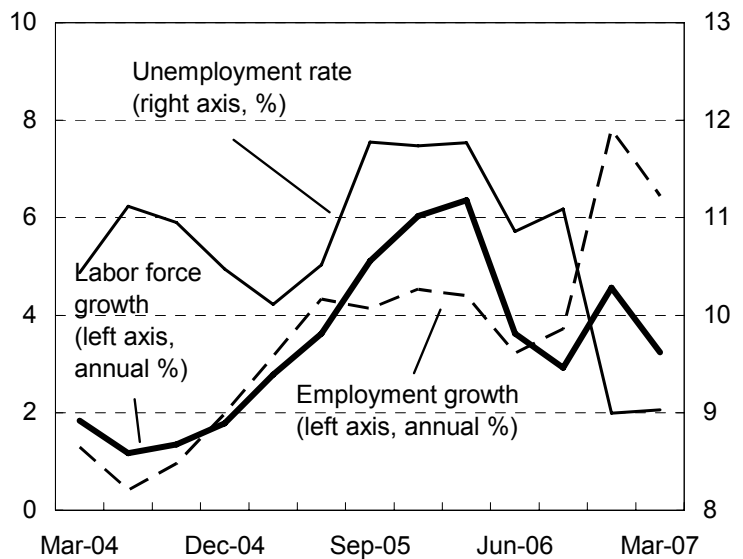

...surging work remittances-mostly from the Gulf region-and Suez canal receipts.

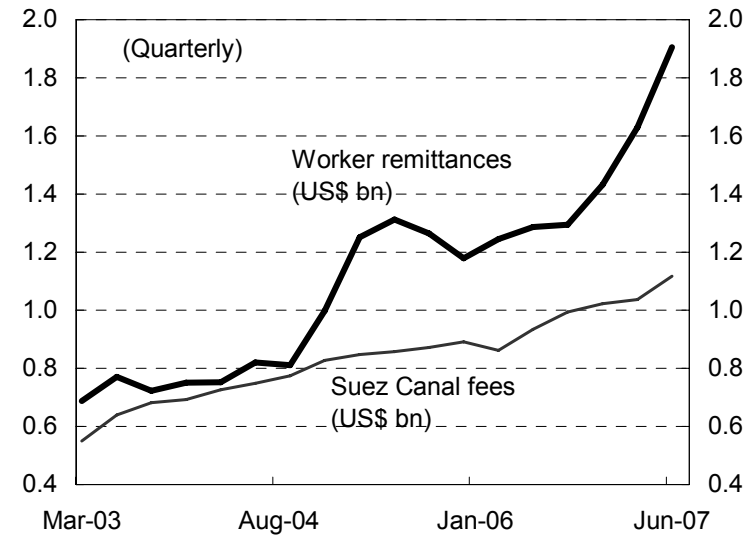

...but P/E ratios only doubled.

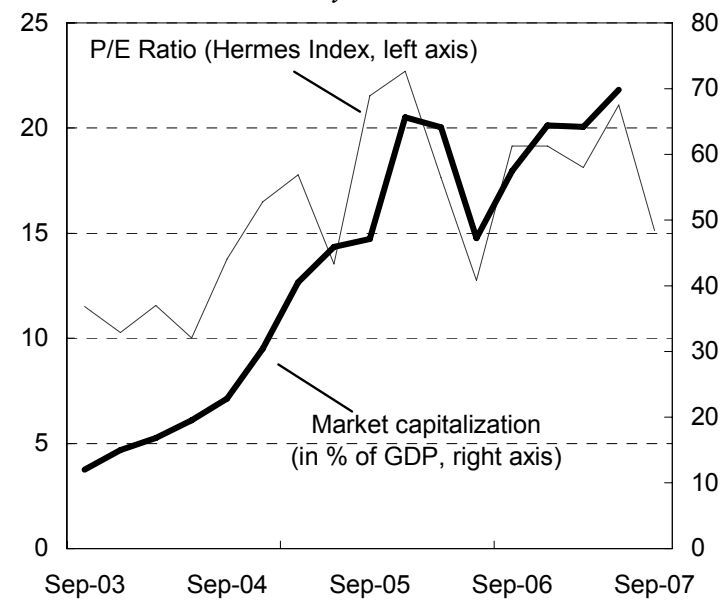


Inflation surged in 2006 and early 2007...

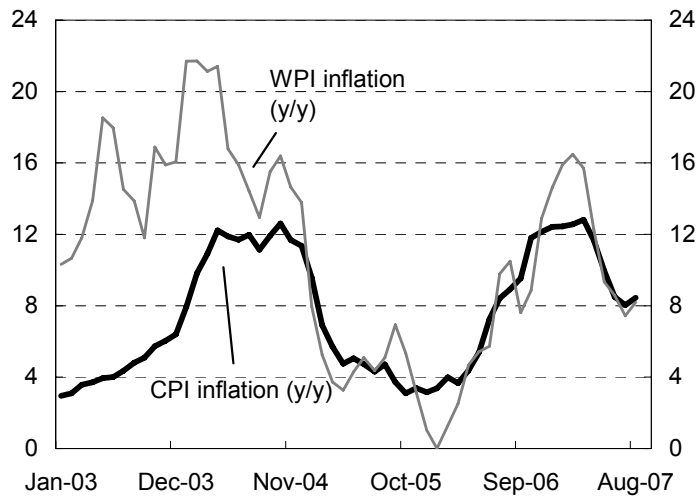

The trade balance weakened as rapid import growth outstripped a sharp rise in exports...

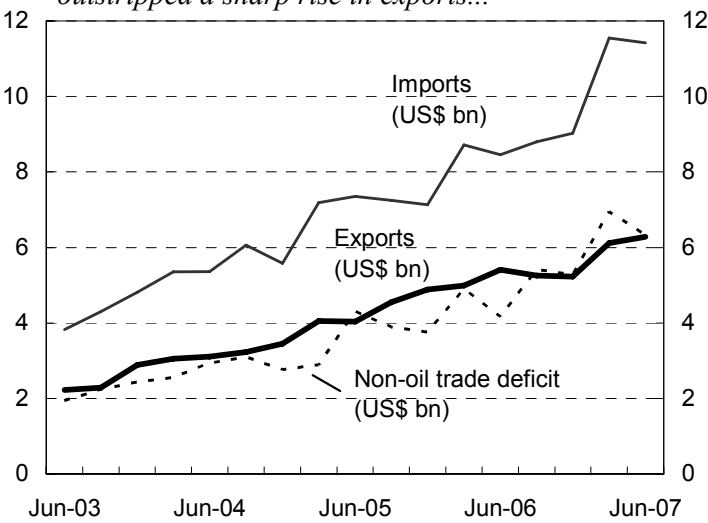

... and the financial and capital accounts registered record levels of FDI and strong portfolio flows.

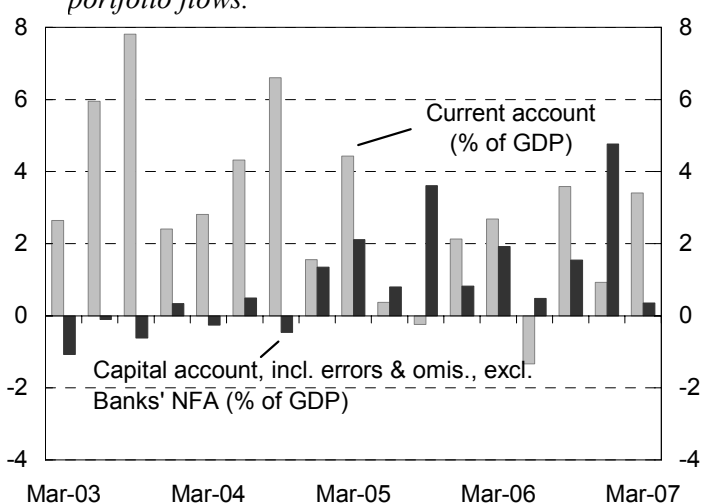

...but has moderated since.

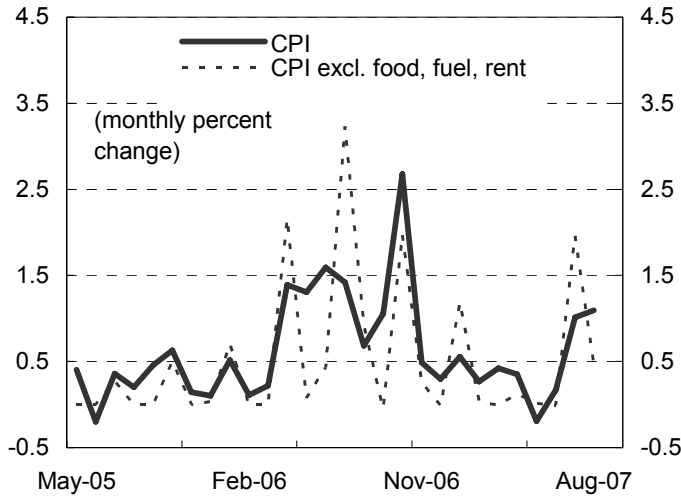

...but other current account inflows did well...

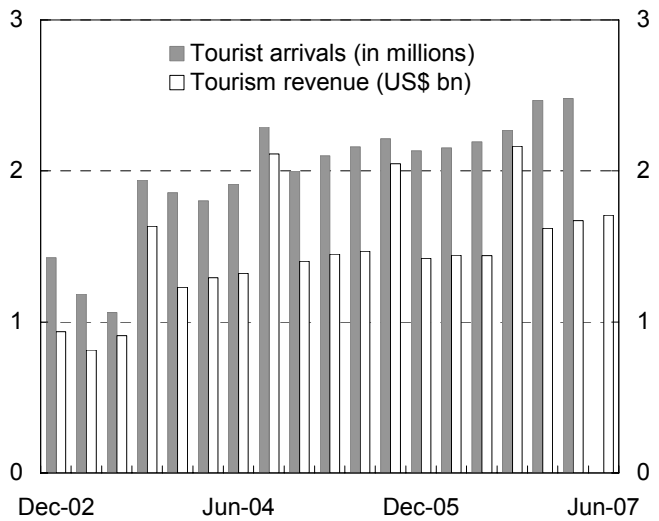

Egypt's integration into the world economy is advancing.

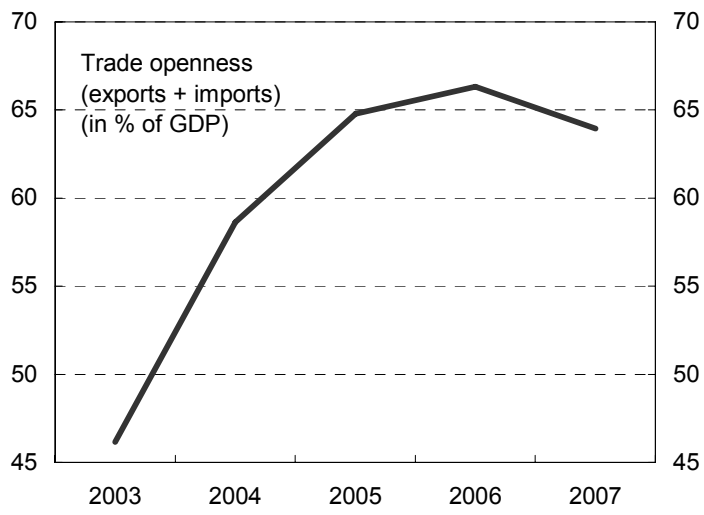


The nominal LE/US dollar exchange rate appreciated by 1.1 percent in the 12 months to July and by another 3 percent through end-October.

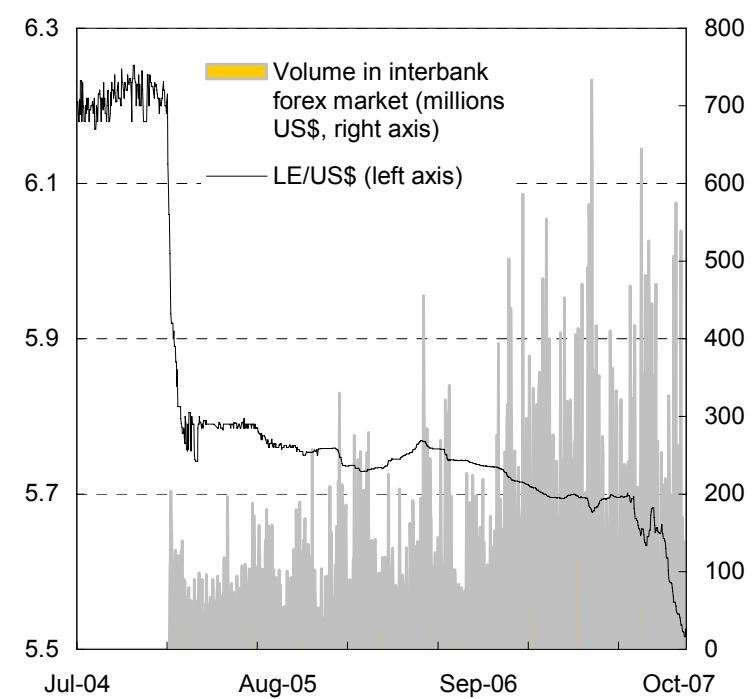

The strong balance of payments surplus combined with the pegged exchange rate resulted in a rapid rise in NIR.

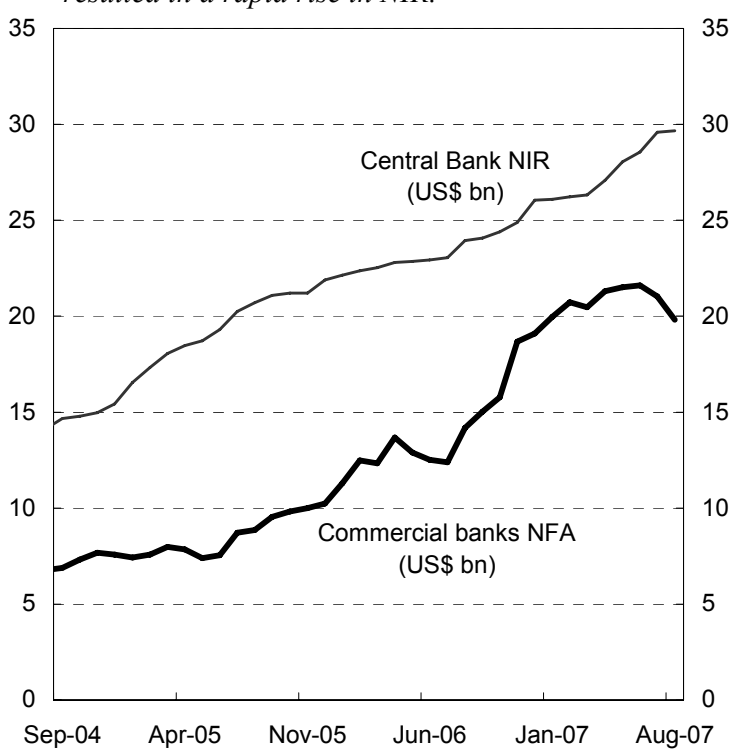

The real effective exchange rate appreciated by 2.2 percent between end-2005 and mid-2007 as Egypt's relatively high inflation was only partly offset by a depreciation of the LE/Euro.

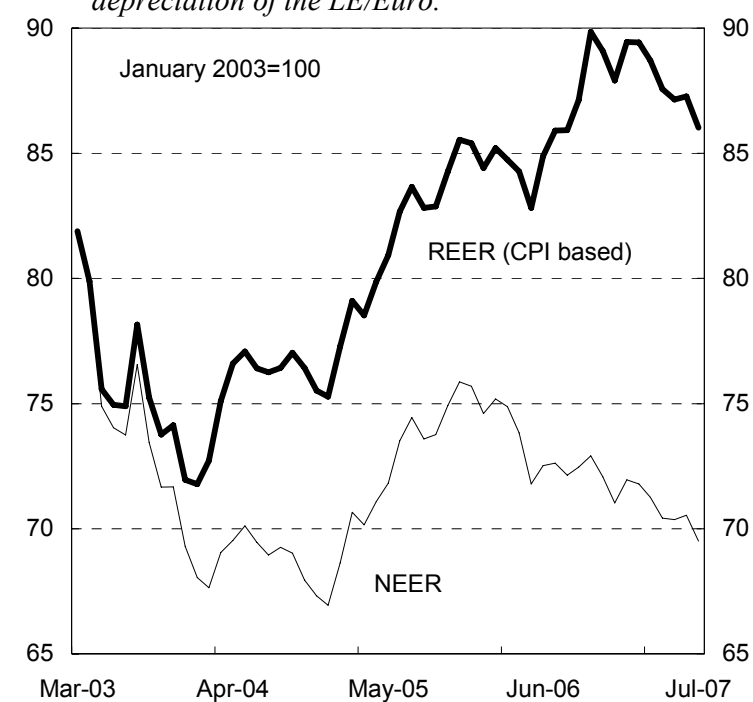

Monetary aggregates have been growing briskly despite heavy sterilization.

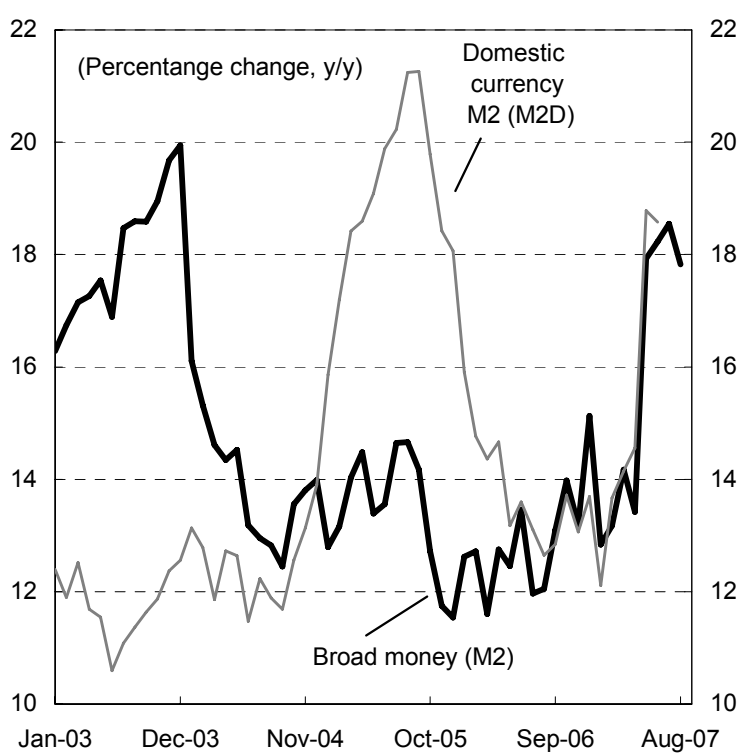


The daily variation of the exchange rate has risen recently...

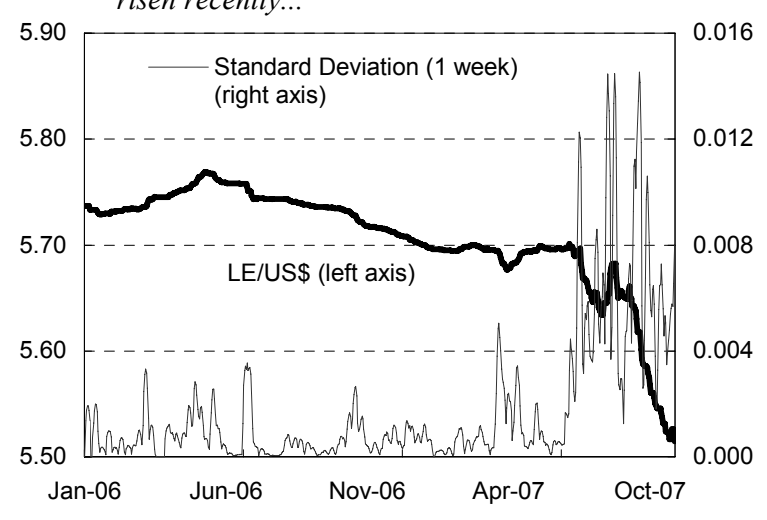

Policy rates were raised in late 2006 but had little lasting impact on bank lending rates and $T$ bill rates.

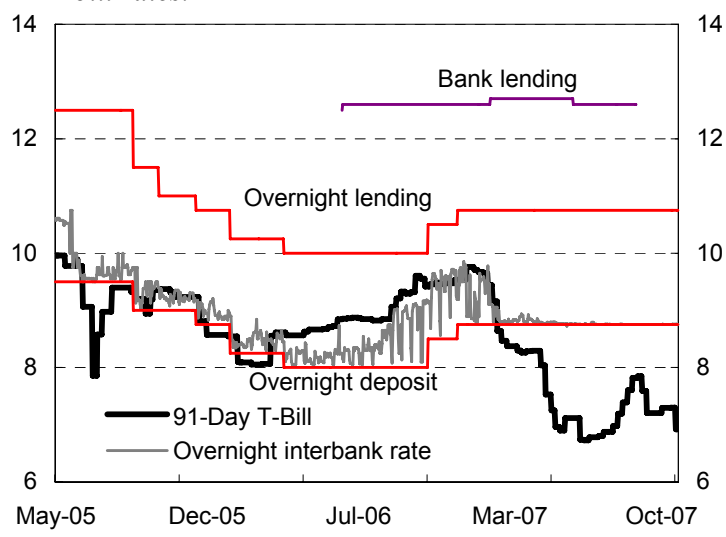

Fiscal adjustment has improved both the overall balance...

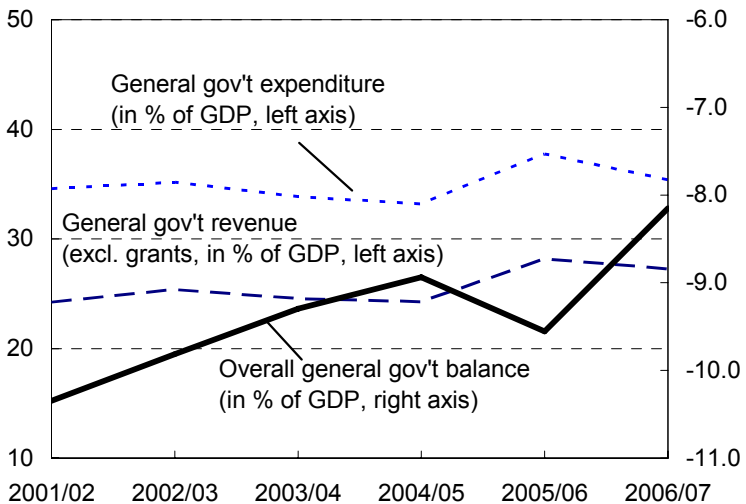

... and LE/US dollar appreciation began accelerating on trend.

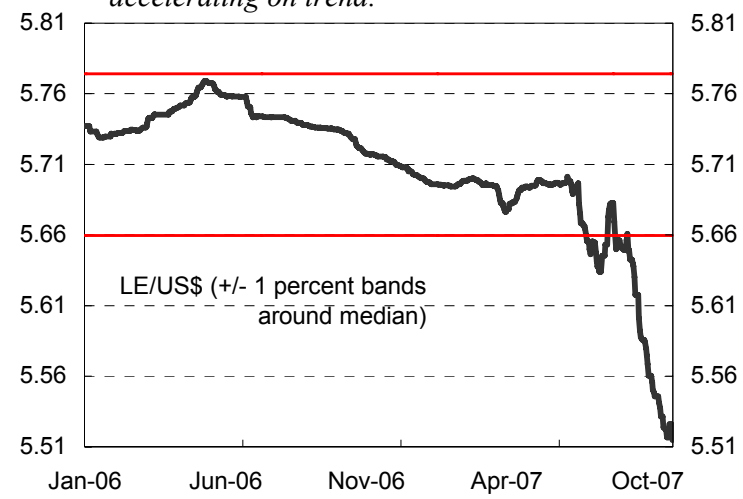

Bond spreads remained well below other emerging markets.

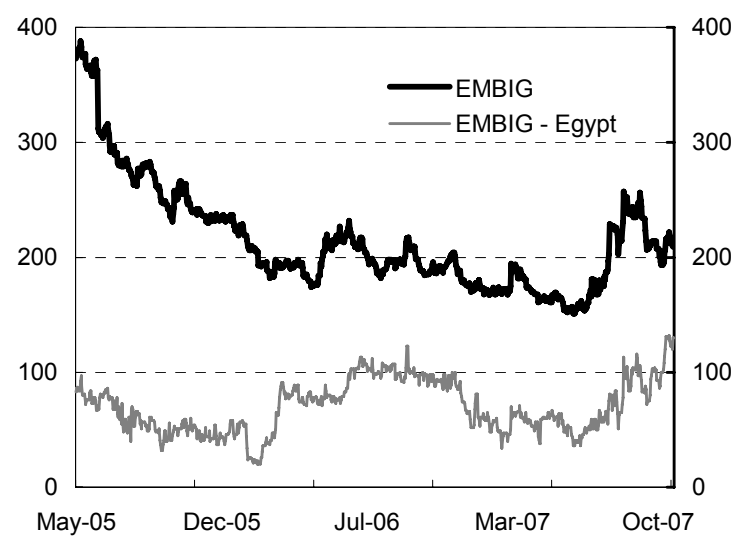

... and the underlying balance, reducing the need for government financing.

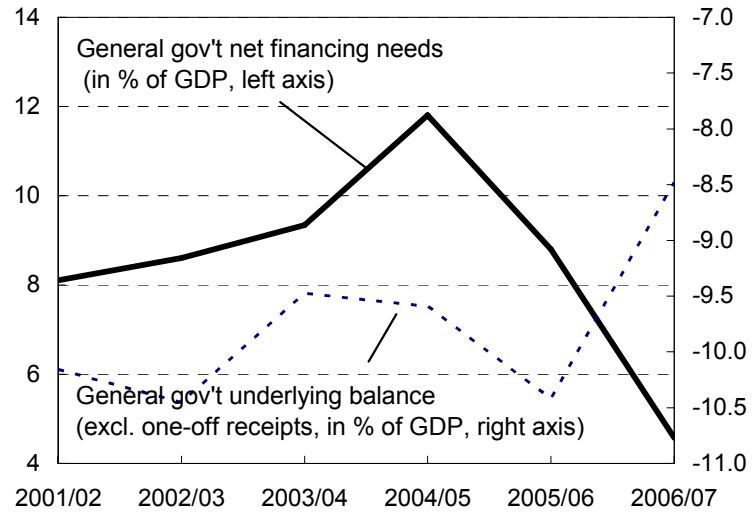


- With surpluses in both the current and the financial accounts, the balance of payments recorded another large surplus in FY 2006/07 (US\$5.3 billion).

- The central bank largely maintained through mid-2007 a de facto peg vis-à-vis the U.S. dollar in the presence of strong appreciation pressures. Broad money growth surged after April to 18 percent as less external inflows were sterilized and money market funds deposited the proceeds from maturing central bank CDs with commercial banks. Annual sterilization costs now approach 1 percent of GDP.

- To rein in inflation, the authorities raised policy rates in late 2006 but the monetary transmission through interest rates was weak. After initially rising with policy rates, overnight and T-bill rates fell, driven by foreign T-bill demand and low budget financing needs; bank lending rates barely moved. ${ }^{4}$

- According to preliminary data, the general government deficit improved from over 9 percent of GDP in $2005 / 06$ to $73 / 4$ percent in $2006 / 07$, while the central government deficit improved from 8.2 to $7 \frac{1}{2}$ percent. The underlying central government balance, i.e., excluding one-off factors,

\begin{tabular}{|lrrr}
\hline \multicolumn{4}{c}{$\begin{array}{c}\text { Central Government Balance } \\
\text { (in percent of GDP) }\end{array}$} \\
\hline & $2005 / 06$ & $2006 / 07$ & $2007 / 08$ \\
& & Est. & Proj. \\
\hline & -8.2 & -7.5 & -7.0 \\
\hline Overall Balance & 24.5 & 24.1 & 22.8 \\
Revenues & 1.1 & 2.5 & 0.6 \\
Of which: one-off revenues 1/ & 33.6 & 29.8 & 29.6 \\
Expenditures & 0.0 & 0.3 & 0.2 \\
Of which: one-off investments & -1.0 & 1.8 & 0.2 \\
Net acquisition of financial assets & -1.1 & 1.2 & 0.0 \\
Of which: one-off acquisitions 2/ & -10.4 & -8.5 & -7.4 \\
Underlying overall balance & 23.4 & 21.6 & 22.2 \\
Revenues & 33.6 & 29.5 & 29.4 \\
Expenditures & 0.1 & 0.6 & 0.2 \\
Net acquisition of financial assets & & & \\
\hline
\end{tabular}

1/ Includes: (i) in 2005/06 forward sale of oil; (ii) in 2006/07 mobile license fee ( 2.1 percent) and reclassified revenues; and (iii) in 2007/08 other license fees.

2/ Includes receipts from sale of $20 \%$ stake in Egypt Telecom and bank assets in 2005/06 (1.1 percent), bank restructuring costs ( 0.8 percent) and reclassified revenues (0.4 percent) in 2006/07. improved by about 2 percentage points of GDP, largely from wage restraint and savings on subsidies, transfers, and interest payments due to cash and debt management reforms (see text table). A significant increase in domestic fuel prices helped contain the fuel subsidy bill. ${ }^{3}$

- Structural reforms advanced significantly in promoting a private sector driven economy.

$>$ The fourth largest state bank (Bank of Alexandria) and a large department store chain, along with smaller firms and unused public land, were sold to foreign investors for the equivalent of about 1.3 percent of GDP.

\footnotetext{
${ }^{4}$ See Selected Issues Paper on monetary transmission.

${ }^{3}$ Domestic fuel prices were raised in July 2006 for diesel (increase of 25 percent), gasoline and natural gas (30 percent), and kerosene (88 percent).
} 
The weighted average import tariff (excluding alcoholic beverages) was reduced from 9 to 6.9 percent in early 2007, and tax administration reforms (modernization of tax and customs procedures, the merger of the income tax and sales tax departments into a single tax authority, and the setting up of large and medium tax-payer offices - the latter on a pilot basis) have progressed, with substantial TA provided by FAD.

$>$ Cash and debt management were streamlined by the consolidation of major government accounts into a treasury single account (TSA) and by the settlement of circular debts among the central government, the National Investment Bank, and the Social Insurance Funds.

$>$ In July 2007, Egypt successfully issued its first international local-currency bond (LE 6 billion), seeking to widen the pool of investors and foster the establishment of a meaningful benchmark yield curve.

Plans to restructure the pension system with World Bank assistance are underway.

The government is putting in place an institutional framework for private-public partnerships (PPPs). A central monitoring unit was set up and legislation providing a broad framework for concessions, PPPs, and leasing will soon be submitted to parliament. PPP projects in the pipeline include building and maintaining 2,100 public schools, four hospitals, several potable and waste water stations, and two freeways. These projects are relatively small and would have only a limited fiscal impact in the next few years.

Recent steps to facilitate business activities included reducing the time, fees, and minimum capital required to set up a business; sharply lowering fees for registering property; and cutting further the time needed for imports and exports to clear customs. 


\section{Box 1. What Explains Inflation Developments in 2006/07?}

Egypt experienced a surge in inflation between March 2006 and March 2007 (see charts). Inflation began to moderate after March 2007, with the CPI falling steadily to 8 percent (y-o-y) by July. The CPI rose again to 8.5 percent in August largely because of an increase in food prices.

Supply shocks: An avian flu outbreak in February 2006 (resulting in the destruction of large chicken stocks, quickly affecting meat and egg prices) and administered fuel price hikes in July 2006 (raising prices for various fuels by 25 to 90 percent) had a sharp impact on prices, and headline inflation rose until early 2007.

Higher world commodity prices: The surge in world prices for several commodities (the global food price index increased by 10 percent in 2006) also contributed to inflation. Some imported food items such as wheat, oils, and sugar are heavily subsidized by the government, but these constitute only about 3-4 percent of the CPI basket by weight compared to 40 percent for all food items. Prices of domestic agricultural produce have also risen because of higher prices for imported fertilizer and seeds.

Demand-side factors and supply bottlenecks: With aggregate demand in Egypt boosted by high growth, rising employment, and wealth effects, signs of demand pressures have emerged. One is the rise in prices not directly affected by supply shocks, such as the CPI excluding food, fuel, and rent (from 2.6 percent (y/y) in February 2006 to 10.6 percent a year later), and similarly the CPI excluding tradables. Another is the surge in imports. While capacity utilization is not high and unskilled labor is ample, there are bottlenecks in some input markets - for example,

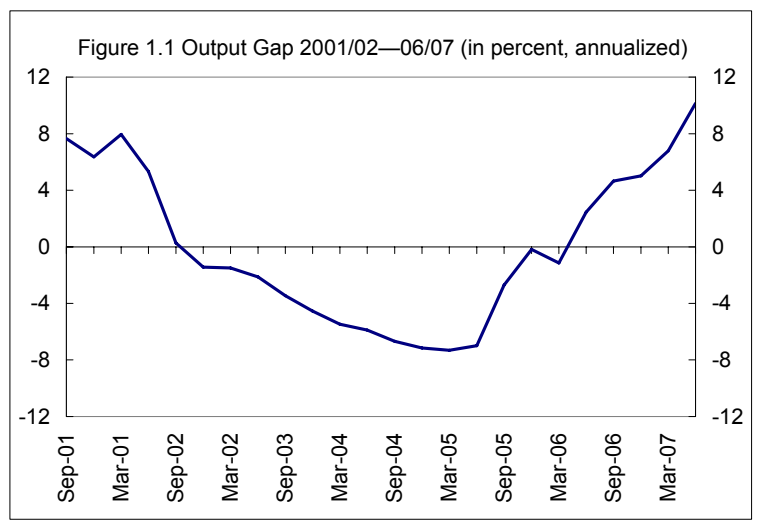
skilled labor and cement. More generally, as the Egyptian economy has been booming since early 2005, it possibly went beyond one measure of potential output (estimated long-run trend GDP) in early 2006, adding to inflationary pressures. 


\section{EgyPT's MEdium-Term POLICY Framework}

5. Egypt's medium term prospects are favorable, provided the external environment remains supportive, the government reduces the deficit by about 1 percent of GDP per year as planned, and efforts continue to overcome structural constraints to business development.

- Growth is projected to remain at 7-8 percent, assuming continued improvement in the business environment succeeds in raising investment to levels over 25 percent of GDP, while other reforms improve the quality of public expenditures (Table 4).

- Foreign capital will play an increasing role in financing investment. Staff projects that the current account will turn into a deficit of about 2 percent of GDP over the medium term, to be financed largely by foreign direct investment (FDI) and a small increase in borrowing.

- The current account would remain close to norms derived from macroeconomic fundamentals and the Egyptian pound broadly in line with fundamentals (see Box 2).

6. The risks from external shocks are low, but a weakening of the reform effort could harm investor confidence and growth:

- The probability of a sudden stop of capital inflows is low. While Egypt has seen a significant increase in capital inflows in the recent past, only a small part is portfolio investment, while the rest is FDI. Geographically, the origin of the capital is also diverse (mostly from Europe, the GCC, and the United States).

- The vulnerability to a sudden stop is also low because the capital inflows have not been intermediated through the financial system and official reserve levels are comfortable. Stress tests conducted during the recent FSAP update suggest that the banking system is mainly vulnerable to a deterioration in domestic credit quality, whereas vulnerability to exchange or interest rate movements is low.

A weakening of the reform effort could threaten the bright medium-term outlook. The positive investor view of the Egyptian economy is largely because of the economy's continuing liberalization since 2004, and in particular the willingness of the government to place public debt on a sustainable path. Any dilution of the reform agenda (because of reform fatigue or adverse political developments) could affect investment incentives and growth. Without fiscal adjustment, growth would be lower and debt sustainability worse over the medium term. 
Box 2. Egypt's Current Account and Equilibrium REER ${ }^{5}$

Egypt's external current account (CA) has been in surplus (but on a declining trend) during the past six years. The large downward correction of the nominal and real exchange rates during 2001-03 boosted competitiveness, the oil boom in the GCC region has increased remittances, and Egypt has emerged as a major liquefied natural gas (LNG) exporter. At the same time, the improved availability of foreign exchange and liberalization of trade facilitated a dramatic increase in non-oil merchandise imports, from US\$13 billion in FY03 to US\$34 billion in FY07. Factoring in the full impact of the real appreciation and reduction in import tariffs in recent years, the present underlying CA balance is estimated to be in a range of 0 to -1 percent, compared to a projected surplus of 0.8 percent in 2007/08.

Using CGER-type methodologies, the external sustainability (ES) approach and the macroeconomic balance (MB) approach indicate a range for the long-run equilibrium $\mathrm{CA}$ balance ("norm") of $-1 / 2$ to $-2 \frac{1}{4}$ percent of GDP, close to the underlying balance. Under the baseline scenario, a CA balance of -0.8 percent of GDP would stabilize Egypt's net foreign assets (NFA) at about -9 percent of GDP, the 2005 level, while under the low growth scenario a CA deficit of 0.5 percent would stabilize NFA. The MB approach, a panel-derived estimate of the CA as a function of a set of macroeconomic fundamentals, indicates an equilibrium balance ("CA norm") of about -1.7 to -2.3 percent of GDP for Egypt, which would stabilize NFA at around -24 percent of GDP.

In the medium term, the $\mathrm{CA}$ is projected to turn into a deficit and remain close to the norms. Strong reforms and a narrowing of the fiscal deficit in line with the authorities' plans are expected to result in continued strong growth and higher investment, and the CA balance is projected to move to -2.2 percent of GDP over the next 5 years. If the fiscal deficit reverts back to 8-9 percent of GDP and structural reforms lose momentum, growth and investment would moderate over time and the CA would settle at around -1.0 percent of GDP. Under either scenario, external stability would be expected to be maintained over the medium term.

\section{Staff estimates suggest that the REER is broadly in line with fundamentals.}

- With the present underlying CA balance within the range indicated by the various norms, no REER adjustment is required to ensure external stability.

- Another staff exercise indicates the existence of a long-run cointegrating relationship between Egypt's REER and key fundamentals. Similar to results found in the literature, the equilibrium REER was found to appreciate with a

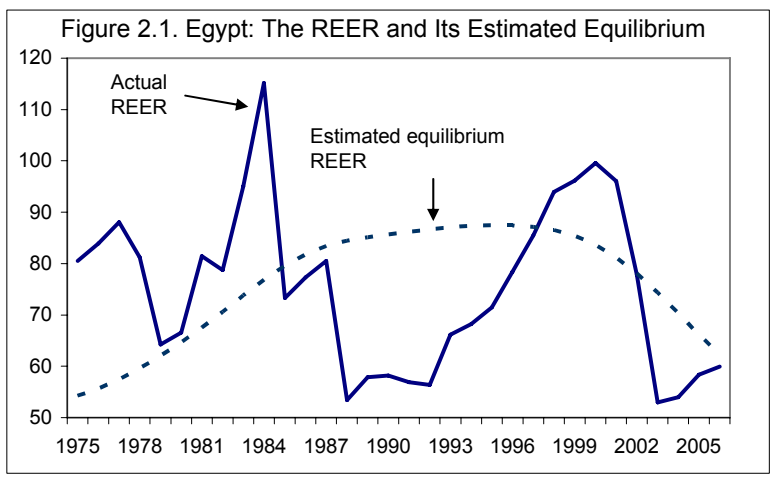
strengthening of Egypt's relative productivity (proxied by per capita GDP relative to trading partners) and exogenous current account inflows (Suez canal fees, official and private remittances, net oil exports, and tourism inflows), but depreciate with greater trade openness. Over the last 15 years, Egypt's equilibrium REER has been on a declining trend mostly driven by relatively weak productivity growth and more recently higher trade openness. The actual REER deviated at times substantially from the estimated equilibrium REER, but by 2006, the gap had virtually closed.

\footnotetext{
${ }^{5}$ See the Selected Issues Paper for greater detail.
} 


\section{Policy Discussions}

Discussions focused on the authorities' macroeconomic policy stance which is geared toward sustaining high growth and creating jobs for a rapidly growing labor force.

\section{A. Getting the Policy Mix Right}

\section{Fiscal policy}

7. Fiscal consolidation remains the overarching priority. It is key for raising national savings to finance the higher investments needed. Given that net public debt is still high at over 70 percent of GDP, it is also critical for consolidating domestic stability and reducing any debt overhang effects on investment. Social expenditures are less efficient in improving health, education, and poverty indicators than in many other countries. ${ }^{6}$ In particular, food and fuel subsidies remain high, at about 7 percent of GDP. The under-pricing of energy promotes excessive consumption with high environmental costs and has little impact on poverty, ${ }^{7}$ while attracting investment into sectors where Egypt may not have a long-run comparative advantage, and implies high effective rates of protection in energy-intensive industries.

8. The authorities are committed to reduce the fiscal deficit to 3 percent of GDP by 2010/11, which would put debt dynamics on a sustainable path and create space for private sector-led growth (see Table 8 and Figure 3). Planned adjustment measures include further energy subsidy reductions, including the phasing out, over 3 years, of gas and electricity subsidies to energy-intensive industrial users; containment of wage bill growth, among other things by a partial hiring freeze; sales tax reforms aimed at moving to a fullfledged value-added tax (VAT) — by widening coverage to services, unifying rates, and raising the exemption threshold; and continued improvements in tax administration. In line with this strategy, the 2007/08 central government budget aims to contain the deficit at 7 percent of GDP, implying an underlying adjustment of more than 1 percent of GDP (Table 2). Such fiscal consolidation would also support monetary policy in reducing demand pressures and contain speculative inflows. The rapid introduction of the sales tax reform and of the planned energy subsidy cuts will be critical to achieve the target.

\section{Monetary and exchange rate policy}

9. The exchange rate is not misaligned, but the de facto peg in place through mid2007 has complicated the task of short-term stabilization. Staff discussed recent estimates that indicate that the rate is boadly in line with fundamentals (see Box 2). However, staff underscored the complications arising from attempts to target both inflation and the exchange rate, especially given Egypt's growing integration in global capital markets. The authorities in this context concurred that capital controls would be an ineffective and costly approach to dealing with short-term inflows.

\footnotetext{
${ }^{6}$ Selected Issues Paper.

${ }^{7}$ SeeCR/06/253, Box 3.
} 
10. The authorities' reaffirmed their commitment to a managed float and an eventual inflation targeting regime. They agreed that allowing greater flexibility need not preclude the Central Bank of Egypt (CBE) from smoothing volatility from one-off flows, but might help to discourage speculative inflows by forcing investors to internalize exchange rate risk. They shared concerns about high sterilization costs and noted staff views that any modest appreciation should help dampen inflation and would be unlikely to affect the competitiveness of Egyptian exports, especially because of the sharp nominal depreciation vis-à-vis the euro since end-2005 (Europe is the main export destination). The CBE pointed to the increased volatility of the exchange rate since July 2007 as evidence of a move away from the de facto peg.

11. The CBE intends to pursue its current approach of broadly targeting underlying inflation. The $\mathrm{CBE}$ has been working on constructing "core inflation" measures, which exclude the most volatile food items as well as items subject to administered prices, and would constitute a useful gauge of underlying inflation. The authorities believed that their publication would greatly enhance communication of the CBE's policy to the public, but plan to wait for the new CPI data to become available. Staff shares the authorities' expectation that in the near term underlying inflation will remain in single digits, provided monetary policy remains vigilant. Should the recent surge in broad money prove less temporary than thought, and the recent appreciation insufficient to curb inflationary pressures, some further tightening might be required.

12. Despite rising rapidly last year, Egypt's reserves remain broadly in line with other emerging market peers (Figure 2). However, they do carry rising costs (including sterilization costs). The authorities see the recent high reserve accumulation largely as a response to one-off inflows, providing the opportunity to build a cushion against external vulnerabilities, largely achieved by now. There is a risk that the CBE's placement of foreign exchange with commercial banks could fuel growth in dollar-denominated bank credits. However, the authorities observed that the risk of a dollar-denominated credit boom is low as commercial banks have deposited most CBE foreign currency placements overseas and domestic foreign currency borrowing is open only to clients engaging in external trade transactions. They plan to carefully monitor commercial banks' use of the CBE's foreign exchange placements.

\section{B. Financial Sector Reforms for Growth and Stability}

13. Having progressed well on bank reforms, the authorities are expanding their reform agenda to other parts of the financial system. Recent reforms (see Box 3 ) have revitalized bank lending to both households and corporates. In addition to the planned privatization of Banque du Caire, the authorities are also focusing on the stock market and 
Box 3. The 2007 Financial Sector Assessment Program (FSAP) Update

A joint IMF-World Bank mission updated in May 2007 the 2002 FSAP. The mission found that substantial progress was made since the launch of the government's 2004 financial sector reform program especially in building a more efficient banking system, but that major challenges remainnotably in modernizing supervision and dealing with substantial public ownership.

\section{Progress since the 2002 FSAP}

The transformation of the Egyptian financial sector has been underway since the authorities began implementing the comprehensive reform program; most of the recommendations of the 2002 FSAP are being implemented.

- $\quad$ Banking reforms include a new banking law, the exit of several weak banks, large-scale financial restructuring involving the buy-out and provisioning of nonperforming loans, the divestiture of state shares in joint venture banks (about 17 percent of banking assets), significantly enhanced banking supervision, and the privatization of one major public bank (Bank of Alexandria, 5 percent of banking assets). As a result, the private sector now owns the majority of banking assets.

- $\quad$ Reforms in money and foreign exchange markets include the 2004 unification of the various exchange rates, the removal of several nonmarket restrictions, and further development of capital markets, which have grown significantly as a result of privatization, regulatory reform, and foreign interest in equity markets.

\section{Completing Financial Reforms}

To ensure the financial sector contributes to sustainable growth of the economy, the next round of reform should further strengthen bank supervision, develop the nonbank sector, and diversify the financial system. In particular, it is necessary to

- $\quad$ improve bank supervision data and analysis; continue to move from compliance-based to riskbased supervision practices; and address, in due course, the potential conflicts of interest in the transitional arrangements for the composition of the CBE's board and the accumulation of management and supervisory functions;

- $\quad$ assign remaining state banks monitorable goals and performance contracts, and reconsider the role of the three small specialized state banks, leading to possible consolidation;

- further improve the collateral regime by expanding the admissible types of securities and better enforcing the new foreclosure rules;

- $\quad$ reduce surplus liquidity in the foreign exchange and money markets and remove the end-of-day foreign exchange clearing facility to allow greater market determination of the exchange rate in line with the de jure float;

- $\quad$ further enhance private equity and establish corporate fixed income markets, including by addressing outstanding regulatory issues such as cumbersome legal procedures that hamper corporate bond issuance, further privatizations that include public IPOs, strengthening the stock exchange's role by clarifying its ownership and governance structure, and building an institutional investor base;

- $\quad$ restructure and at least partially privatize state insurers, enact key sector legislation (including on mandatory third party liability insurance, and allowing market-based premia), and move further toward risk-based regulation and supervision.

- $\quad$ ensure a smooth integration of nonbank supervisory agencies, aimed at establishing a common risk-based approach harmonizing governance, staff skills, and supervisory focus. 
the nonbank financial sector (mortgage, insurance, public and private pension system) with a view to enhance financial intermediation, attract savings, and finance economic growth. While past stock market capitalization gains have mainly come from price effects (as opposed to initial public offerings), the authorities pointed to the growing role of private placements.

\section{The authorities plan to complete in the near future the 2004 financial sector} reform program, in line with some of the FSAP recommendations.

- On restructuring of state banks, they have largely cleaned up Banque du Caire's nonperforming loan portfolio and its sale is expected to be completed by mid-2008.

- A new credit bureau began operations in July and is expected to expand its database further, significantly enhancing banks' information set in consumer lending.

- To enhance the role of equity markets in mobilizing corporate finance, the listing process is being simplified and the delisting of little-traded companies accelerated. Plans are underway to establish a small-cap exchange.

- In insurance, the viable state insurance companies - that still dominate both life and nonlife insurance markets as well as reinsurance - are being merged to form a "national champion"- the largest insurer in the Middle East. Later, there may be a partial float of shares to enhance market discipline.

15. The authorities expressed concerns about implementing some recommendations of the FSAP update. On the transition to risk-based bank supervision, the authorities felt the FSAP assessment did not adequately acknowledge progress achieved in upgrading regulations and staff skills. On the management of remaining state banks, the CBE emphasized the importance of proper supervision but did not see a need for performance contracts.

\section{Other Issues}

16. Further improvements in macroeconomic statistics are needed. Egypt subscribed to the SDDS in January 2005, but data deficiencies persist in many sectors. The mission urged the authorities to implement the recommendations made in the 2003 data ROSC and improve the overall production of statistics (Appendix III), attaching particular urgency to timely and accurate data on the oil and gas sector. Progress in implementing a comprehensive foreign investment survey needs to speed up.

\section{Staff APPRAisal}

17. Egypt's economy delivered another impressive performance in 2006/07. Farreaching reforms since 2004 and solid macroeconomic management supported by a favorable global and regional economic environment are paying off as the economy experiences its highest growth in years, with substantial gains in employment. A temporary run-up in 
inflation was partly the result of overdue fuel-price adjustments. While monetary policy rightly focused on containing spillovers from administered price increases, the effectiveness of policy implementation was hampered by insufficient exchange rate flexibility. The de facto peg has also contributed to rising sterilization costs and to the import of global food price inflation into Egypt, which has triggered increasingly vocal popular concerns that may complicate future reforms. In staff's view, the experience of the last 3 years provides some important lessons that should guide policies going forward.

18. Reforms have paid off, and continuing the government's reform agenda is essential to further reduce high unemployment and sustain high growth. Building on the impressive gains made since 2004, this will require domestic and external stability anchored by a consistent macroeconomic policy framework, fiscal adjustment, and legal and regulatory reform that reduce red tape and facilitate contract enforcement.

\section{The government's plan to reduce the deficit gradually to 3 percent of GDP} by 2010/11 is appropriately ambitious and would put public debt on a firmly declining path. In line with this strategy, meeting the 2007/08 central government deficit target of 7 percent of GDP will be important. Achieving the short and medium-term fiscal targets will require policy measures such as forceful reductions in energy subsidies, continued retrenchment in the wage bill, reform of the sales and property taxes, and improvements in the efficiency of cash management and public spending. In particular, the planned phase-out of gas and electricity subsidies for energy intensive industries, if implemented quickly, would contribute sizably toward meeting the medium-term targets. While staff sees considerable scope for delivering better public services in all social areas, energy subsidies constitute the most glaring example of unproductive public spending and offer ample room for reducing spending. At the same time, efforts should continue to strengthen social safety nets to protect the poorest segments of society. PPPs should be introduced gradually to minimize risks and allow learning from experience.

20. In staff's view, the favorable economic environment provides an opportunity to put the crucial supporting fiscal measures in place early on both to help deliver the 2007/08 budget target and to enhance the credibility of the reform program, thereby contributing to a strong and swift investor response. Many of these measures are politically difficult, and building the necessary consensus, including through transparent communication, will be important. But the continued increases in international food and fuel prices, which will drive up the food and subsidy bill, has made strong and timely action even more pressing.

\section{Staff concurs that the authorities' choice of a managed float regime is an} appropriate framework to deliver macroeconomic stability. A flexible rate acts as a natural stabilizer in dealing with real shocks, including capital flows - relevant features of the Egyptian economy. Furthermore, Egypt has the institutions and capacity to implement an independent monetary policy, and owing to prudential regulations and limited dollarization, the balance sheets of neither the banking nor the corporate or household sectors appear particularly vulnerable to currency swings. 


\section{Staff estimates that the Egyptian real exchange rate is broadly in line with}

fundamentals. The recently observed greater flexibility of the exchange rate is a welcome step toward a more consistent policy framework based on a managed float, consistent with the planned move to inflation targeting. Greater exchange rate flexibility is essential to make monetary policy an effective tool for liquidity management, eliminate the one-way bet on the currency, and lower sterilization costs. The central bank will need to continue to focus on and respond to developments in available measures of underlying inflation.

\section{Staff strongly supports the authorities' plans to move ahead with further}

financial sector reforms, consistent with recent FSAP recommendations. Over the last two years, privatization has put about half of the banking sector into private hands and resolution of NPLs has advanced well. Staff encourages the authorities to build on the good progress made to date, and continue to improve bank and nonbank supervision along the lines set out in the banking sector program launched in 2004 and the recent FSAP update. With a predominantly private banking sector, it will be crucial to impose stringent performance standards on remaining state-owned banks and improve monitoring to prevent these banks from defending market shares by taking on higher risks. Complementary regulatory and judicial reforms - such as setting up specialized economic courts and enhancing the role of the private sector-led credit bureau - will also help to improve contract enforcement and creditor protection, thereby addressing key obstacles to bank lending to small and medium enterprises (SMEs). Given the experience with public ownership, staff is skeptical about the idea of building a largely state-owned "national champion" in the insurance sector and believes that it should be gradually privatized.

24. Economic and financial statistics provided to the Fund are broadly adequate for surveillance, but efforts to improve macroeconomic statistics need to continue. Egypt subscribed to the SDDS in January 2005, but data improvements in certain areas are urgently needed. A new CPI series has been published, but greater details on the underlying methodology would be helpful. Progress in implementing a comprehensive foreign investment survey has been slow. Data availability on the production and use of oil and gas needs to be improved, and greater transparency of EGPC's financial situation would help in the rationalization of energy policy. Staff encourages the authorities to implement the recommendations made in the 2003 data ROSC.

25. It is proposed that the next Article IV consultation with the Arab Republic of Egypt take place on the 12-month cycle. 
Figure 1. Egypt: Reserve Benchmark Indicators, FY 2000/01-2006/07 (In percent)
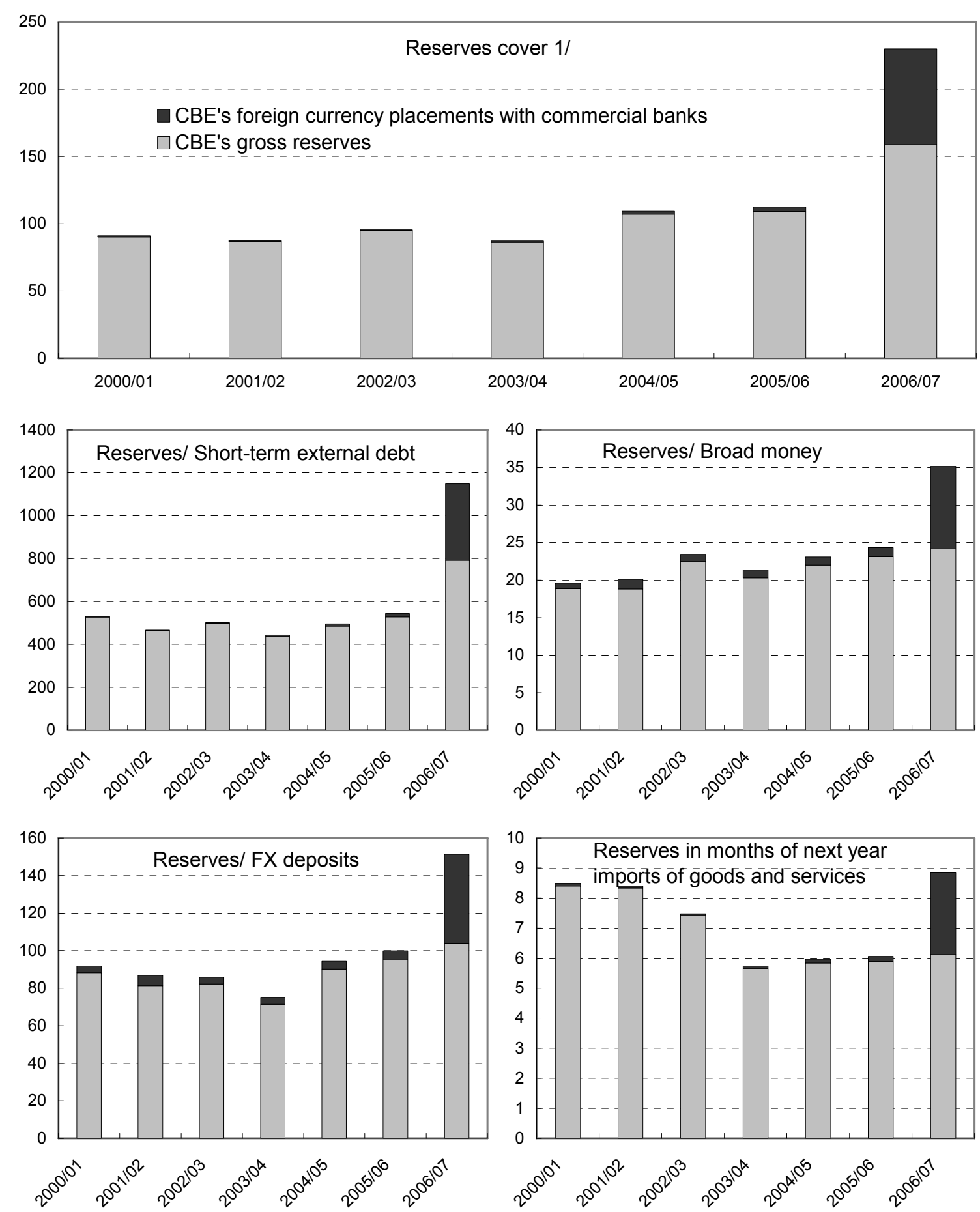

Source: Authorites and staff estimates.

1/ Reserves cover relative to the sum of short-term debt, the current account deficit (adjusted for FDI), and foreign currency deposits in the banking system. 
Figure 2. Egypt and Comparator Countries: Reserve Benchmark Indicators, 1999-2007
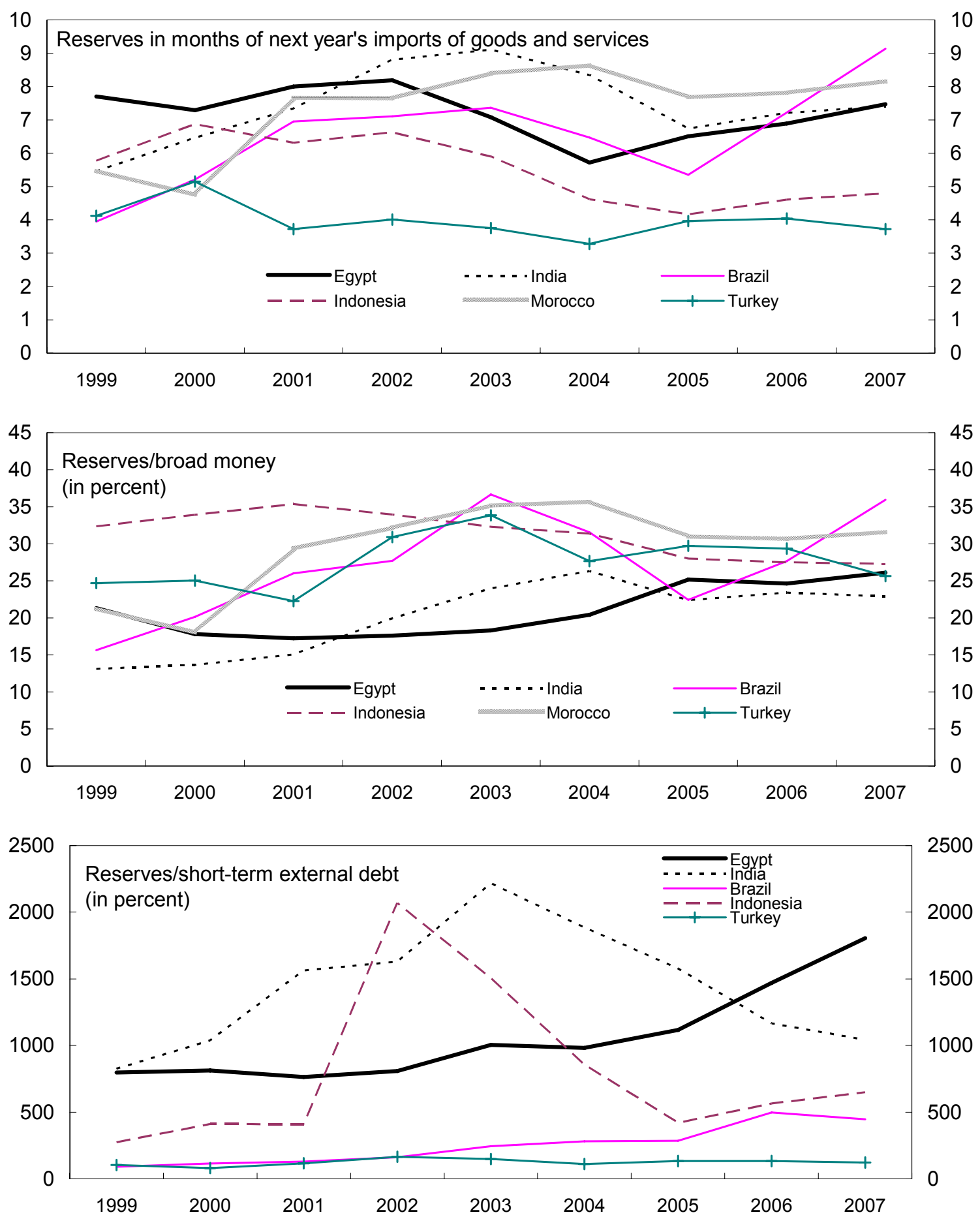

Source: IMF World Economic Outlook, April 2007. 
Table 1. Egypt: Selected Macroeconomic Indicators, 2003/04-2007/08 1/

(Quota: SDR 943.7 million)

(Population 72.1 million; 2006)

(Per capital GDP: US\$1,500; 2006)

(Poverty rate: 19.6 percent, 2005)

(Main products and exports: hydrocarbon products, cotton/textiles, iron and steel products, and tourism; 2006/07)

\begin{tabular}{|c|c|c|c|c|c|}
\hline & $2003 / 04$ & $2004 / 05$ & $2005 / 06$ & $2006 / 07$ & $2007 / 08$ \\
\hline & \multicolumn{3}{|c|}{ Act. } & Prel. Est. & Proj. \\
\hline Output and prices & \multicolumn{5}{|c|}{ (Annual percentage change) } \\
\hline Real GDP (market price) & 4.1 & 4.5 & 6.8 & 7.1 & 7.3 \\
\hline Real non-oil GDP (at factor cost) & 4.4 & 4.9 & 5.8 & 7.1 & 7.5 \\
\hline CPI inflation (end of period) & 11.7 & 4.7 & 7.2 & 8.5 & 7.9 \\
\hline CPI inflation (average) & 8.1 & 8.8 & 4.2 & 10.9 & 7.8 \\
\hline Investment and savings $3 /$ & \multicolumn{5}{|c|}{ (In percent of GDP at market prices) } \\
\hline Gross capital formation & 16.9 & 18.0 & 18.7 & 22.2 & 23.0 \\
\hline Of which: nongovernment (incl. change in inventory) & 12.2 & 13.6 & 15.3 & 18.9 & 19.8 \\
\hline Gross national saving & 21.3 & 21.2 & 19.5 & 23.5 & 23.8 \\
\hline Of which: nongovernment & 22.6 & 23.9 & 23.8 & 25.5 & 26.8 \\
\hline Public Finances (general government) & \multicolumn{5}{|c|}{ (In percent of GDP at market prices) } \\
\hline Revenue (including grants) 2/ 3/ & 25.6 & 24.8 & 28.6 & 27.8 & 26.0 \\
\hline Expenditure 3/ 4/ & 31.7 & 31.8 & 36.3 & 32.9 & 32.2 \\
\hline Budget balance $5 /$ & -8.3 & -8.4 & -9.2 & -7.7 & -6.9 \\
\hline Primary balance & -2.5 & -2.8 & -3.4 & -2.3 & -1.9 \\
\hline Total public debt (net) & 82.4 & 80.5 & 79.8 & 72.6 & 69.4 \\
\hline Monetary Sector & \multicolumn{5}{|c|}{ (Annual percentage change) } \\
\hline Credit to private sector & 4.5 & 3.6 & 8.6 & 12.3 & 12.8 \\
\hline Base money 6/ & 8.8 & 0.7 & -5.0 & 14.4 & 17.4 \\
\hline Broad money (M2) & 13.2 & 13.6 & 13.5 & 18.3 & 16.8 \\
\hline Velocity of broad money & 1.12 & 1.09 & 1.10 & 1.10 & 1.10 \\
\hline Treasury bills (91-day rate, period average, in percent) & 8.4 & 10.2 & 8.8 & 8.7 & $\cdots$ \\
\hline External sector & \multicolumn{5}{|c|}{ (In percent of GDP) } \\
\hline Exports of goods (in U.S. dollar, percentage change) & 27.4 & 32.3 & 33.4 & 19.3 & 18.8 \\
\hline Imports of goods (in U.S. dollar, percentage change) & 23.4 & 32.3 & 25.8 & 24.3 & 20.5 \\
\hline Merchandise trade balance & -9.9 & -11.5 & -11.2 & -12.4 & -13.0 \\
\hline Current account including official transfers & 4.3 & 3.2 & 0.8 & 1.4 & 0.8 \\
\hline Foreign direct investment & 3.2 & 4.3 & 5.6 & 8.2 & 5.5 \\
\hline Total external debt & 37.9 & 32.2 & 28.8 & 24.2 & 20.2 \\
\hline Gross official reserves (in U.S. dollar billions) & 14.8 & 19.3 & 22.9 & 28.3 & 34.2 \\
\hline In months of next year imports of goods and services & 5.7 & 5.8 & 5.9 & 6.1 & 6.6 \\
\hline In percent of short-term external debt $7 /$ & 437 & 486 & 529 & 794 & 899 \\
\hline \multicolumn{6}{|l|}{ Memorandum items: } \\
\hline Nominal GDP (in US\$ billions) & 78.8 & 89.8 & 107.4 & 127.9 & 149.7 \\
\hline Unemployment rate (percent) & 11.1 & 10.5 & 10.9 & 9.0 & $\cdots$ \\
\hline Net hydrocarbon exports (in US\$ billions) & 1.3 & 1.3 & 4.9 & 6.0 & 6.4 \\
\hline Egyptian pounds per US dollar (period average) & 6.16 & 6.00 & 5.75 & 5.72 & $\ldots$ \\
\hline Real effective exchange rate (period average, percentage change) & -21.6 & 4.2 & 8.1 & 4.4 & $\ldots$ \\
\hline Stock market index (CASE 30) & 135.7 & 449.7 & 425.7 & 502.6 & $\ldots$ \\
\hline
\end{tabular}

Sources: Egyptian authorities, World Bank (poverty rate); and Fund staff estimates and projections.

1/ Fiscal year ends June 30.

2/ Authorities' estimates based on revised source data and new budget classification adopted in 2006.

$3 /$ Series break in 2005/06, when fuel subsidies were explicitly recorded, and matched by an equivalent notional revenue (from the

$4 /$ Includes acquisition of financial assets.

5/ As calculated by the ministry of finance but adjusted to (i) include the repayment of past arrears as a capital spending

spending item (purchase of nonfinancial assets), and (ii) eliminate the creation of arrears from the financing side, as well

as from capital spending.

6/ Includes foreign-currency deposits of commercial banks at the central bank.

7/ The estimate for short-term private external debt is likely to be biased downward due to insufficient data. 
Table 2. Egypt: Summary of Budget Sector Fiscal Operations 1/

\begin{tabular}{|c|c|c|c|c|c|c|c|c|c|}
\hline & \multirow[t]{2}{*}{$2003 / 04$} & \multirow[t]{2}{*}{$2004 / 05$} & \multirow[t]{2}{*}{$2005 / 06$} & \multirow{2}{*}{$\begin{array}{r}\text { 2006/07 } \\
\text { Prel. 2/ }\end{array}$} & \multicolumn{2}{|c|}{$2007 / 08$} & \multirow{2}{*}{$\begin{array}{r}2008 / 09 \\
\text { Proj. }\end{array}$} & \multirow{2}{*}{$\begin{array}{r}\text { 2009/10 } \\
\text { Proj. }\end{array}$} & \multirow{2}{*}{$\begin{array}{r}2010 / 11 \\
\text { Proj }\end{array}$} \\
\hline & & & & & Budget & Proj. & & & \\
\hline & \multicolumn{9}{|c|}{ (In billion Egyptian pounds) } \\
\hline Revenue & 101.9 & 110.9 & 151.3 & 176.3 & 187.2 & 193.9 & 226.3 & 256.2 & 291.1 \\
\hline Tax revenue & 67.1 & 75.8 & 97.8 & 113.6 & 120.8 & 123.6 & 147.4 & 167.6 & 191.1 \\
\hline Income and property & 28.1 & 32.6 & 49.5 & 59.1 & 57.6 & 61.0 & 74.9 & 84.2 & 95.1 \\
\hline Goods and services & 26.6 & 31.4 & 34.7 & 39.9 & 45.7 & 46.2 & 53.8 & 61.8 & 70.9 \\
\hline International trade & 9.2 & 7.7 & 9.7 & 10.4 & 13.3 & 11.5 & 13.0 & 15.0 & 17.5 \\
\hline Other taxes & 3.3 & 4.0 & 3.9 & 4.3 & 4.2 & 4.9 & 5.7 & 6.6 & 7.6 \\
\hline Nontax revenue & 29.7 & 32.3 & 51.1 & 59.2 & 63.2 & 67.1 & 75.6 & 85.2 & 96.4 \\
\hline Of which: mobile license fee & 0.0 & 0.0 & 0.0 & 15.3 & 5.2 & 5.2 & 0.0 & 0.0 & 0.0 \\
\hline Grants & 5.1 & 2.9 & 2.4 & 3.5 & 3.2 & 3.2 & 3.2 & 3.4 & 3.6 \\
\hline Expenditure & 146.0 & 161.6 & 207.8 & 217.7 & 244.1 & 251.3 & 280.3 & 303.7 & 327.4 \\
\hline Wages & 37.3 & 41.5 & 46.7 & 51.5 & 60.3 & 60.3 & 73.8 & 85.1 & 98.0 \\
\hline Purchases of goods and services & 9.3 & 12.6 & 14.4 & 16.0 & 16.9 & 16.9 & 19.7 & 22.7 & 26.2 \\
\hline Interest & 30.7 & 32.8 & 36.8 & 47.6 & 52.0 & 52.0 & 55.0 & 60.9 & 65.7 \\
\hline Subsidies, grants, and social benefits $2 /$ & 24.8 & 29.7 & 68.9 & 58.4 & 64.3 & 77.7 & 95.9 & 108.6 & 123.6 \\
\hline Of which: fuel subsidy & 0.0 & 0.0 & 41.8 & 40.1 & 36.6 & 47.0 & 62.1 & 67.4 & 74.1 \\
\hline Other current expenditure & 21.0 & 21.7 & 19.7 & 20.3 & 22.9 & 22.9 & 26.6 & 30.7 & 35.3 \\
\hline Investment expenditure & 22.9 & 23.3 & 21.2 & 23.8 & 27.7 & 27.2 & 31.7 & 37.2 & 44.3 \\
\hline Measures & 0.0 & 0.0 & 0.0 & 0.0 & 0.0 & -5.7 & -22.3 & -41.6 & -65.7 \\
\hline Cash balance & -44.1 & -50.7 & -56.5 & -41.4 & -56.8 & -57.3 & -54.0 & -47.5 & -36.3 \\
\hline Net acquisition of financial assets & 1.9 & 0.9 & -6.2 & 13.1 & 1.9 & 1.9 & 2.3 & 2.6 & 3.0 \\
\hline \multirow[t]{2}{*}{ Overall fiscal balance } & -46.0 & -51.6 & -50.4 & -54.5 & -58.8 & -59.3 & -56.3 & -50.1 & -39.4 \\
\hline & \multicolumn{9}{|c|}{ (In percent of GDP) } \\
\hline Revenue & 21.0 & 20.6 & 24.5 & 24.1 & 22.2 & 22.8 & 22.9 & 22.5 & 22.2 \\
\hline Tax revenue & 13.8 & 14.1 & 15.8 & 15.5 & 14.4 & 14.6 & 14.9 & 14.7 & 14.6 \\
\hline Income and property & 5.8 & 6.1 & 8.0 & 8.1 & 6.8 & 7.2 & 7.6 & 7.4 & 7.2 \\
\hline Goods and services & 5.5 & 5.8 & 5.6 & 5.5 & 5.4 & 5.4 & 5.4 & 5.4 & 5.4 \\
\hline International trade & 1.9 & 1.4 & 1.6 & 1.4 & 1.6 & 1.4 & 1.3 & 1.3 & 1.3 \\
\hline Other & 0.7 & 0.7 & 0.6 & 0.6 & 0.5 & 0.6 & 0.6 & 0.6 & 0.6 \\
\hline Nontax revenue & 6.1 & 6.0 & 8.3 & 8.1 & 7.5 & 7.9 & 7.7 & 7.5 & 7.3 \\
\hline Of which: mobile license fee & 0.0 & 0.0 & 0.0 & 2.1 & 0.6 & 0.6 & 0.0 & 0.0 & 0.0 \\
\hline Grants & 1.0 & 0.5 & 0.4 & 0.5 & 0.4 & 0.4 & 0.3 & 0.3 & 0.3 \\
\hline Expenditure & 30.1 & 30.0 & 33.6 & 29.8 & 29.0 & 29.6 & 28.4 & 26.7 & 25.0 \\
\hline Wages and other remunerations & 7.7 & 7.7 & 7.6 & 7.0 & 7.2 & 7.1 & 7.5 & 7.5 & 7.5 \\
\hline Purchases of goods and services & 1.9 & 2.3 & 2.3 & 2.2 & 2.0 & 2.0 & 2.0 & 2.0 & 2.0 \\
\hline Interest & 6.3 & 6.1 & 6.0 & 6.5 & 6.2 & 6.1 & 5.6 & 5.3 & 5.0 \\
\hline Subsidies, grants and social benefits $2 /$ & 5.1 & 5.5 & 11.2 & 8.0 & 7.6 & 9.1 & 9.7 & 9.5 & 9.4 \\
\hline Of which: fuel subsidy & 0.0 & 0.0 & 6.8 & 5.5 & 4.3 & 5.5 & 6.3 & 5.9 & 5.6 \\
\hline Other current expenditure & 4.3 & 4.0 & 3.2 & 2.8 & 2.7 & 2.7 & 2.7 & 2.7 & 2.7 \\
\hline Investment expenditure & 4.7 & 4.3 & 3.4 & 3.3 & 3.3 & 3.2 & 3.2 & 3.3 & 3.4 \\
\hline Measures (cumulative) 3 / & 0.0 & 0.0 & 0.0 & 0.0 & 0.0 & -0.7 & -2.3 & -3.7 & -5.0 \\
\hline Cash balance & -9.1 & -9.4 & -9.2 & -5.7 & -6.8 & -6.8 & -5.5 & -4.2 & -2.8 \\
\hline Net acquisition of financial assets & 0.4 & 0.2 & -1.0 & 1.8 & 0.2 & 0.2 & 0.2 & 0.2 & 0.2 \\
\hline Overall fiscal balance & -9.5 & -9.6 & -8.2 & -7.5 & -7.0 & -7.0 & -5.7 & -4.4 & -3.0 \\
\hline Statistical discrepancy & 0.5 & 1.1 & 1.3 & 0.1 & 0.0 & 0.0 & 0.0 & 0.0 & 0.0 \\
\hline Financing & 10.0 & 10.7 & 9.5 & 7.6 & 7.0 & 7.0 & 5.7 & 4.4 & 3.0 \\
\hline Net domestic financing & 9.3 & 11.8 & 8.8 & 4.6 & 6.4 & 6.4 & 5.4 & 4.1 & 2.7 \\
\hline Net external financing & 0.1 & -0.8 & 0.6 & 0.5 & 0.3 & 0.3 & 0.3 & 0.3 & 0.3 \\
\hline Other, of which: & 0.6 & -0.3 & 0.1 & 2.6 & 0.2 & 0.2 & 0.0 & 0.0 & 0.0 \\
\hline Net privatization proceeds & 0.0 & 0.2 & 0.0 & 0.0 & 0.1 & 0.1 & 0.0 & 0.0 & 0.0 \\
\hline \multicolumn{10}{|l|}{ Memorandum items: } \\
\hline Overall balance net of one-off items 4 / & -9.5 & -9.6 & -10.4 & -8.5 & -7.4 & -7.4 & -5.7 & -4.4 & -3.0 \\
\hline Primary balance & -3.1 & -3.5 & -2.2 & -0.9 & -0.8 & -0.9 & -0.1 & 0.9 & 2.0 \\
\hline Oil revenues $5 /$ & 0.6 & 0.9 & 7.8 & 5.5 & 5.2 & 5.8 & 6.5 & 6.1 & 5.9 \\
\hline Nonoil revenue & 20.4 & 19.7 & 16.7 & 18.6 & 17.0 & 17.1 & 16.4 & 16.3 & 16.3 \\
\hline Nominal GDP (in billion LE) & 485.3 & 538.5 & 617.7 & 731.2 & 841.7 & 849.0 & 987.4 & $1,139.2$ & $1,311.8$ \\
\hline
\end{tabular}

Source: Ministry of Finance and Fund staff estimates.

1/ Budget sector comprises central government, local governments, and some public corporations. The fiscal year begins on July 1 . The data are presented on a cash basis consistent with the GFS 2001 classification.

2/ Beginning in 2005/06, the cost of domestic fuel subsidies covered by EGPC is recorded on-budget, with a corresponding counter-entry as notional revenues from EGPC

3/ Measures yet to be implemented (e.g. sales tax reform (approx. 2-2.5 percent of GDP), energy subsidy cuts for industry (approx. 1.5 percent of GDP when fully in place), and fuel subsidy cuts.

4/ Adjusts for one-off receipts from FY2005/06 onward, including the sale of Egypt Telecom, mobile license fee, and other.

5 / Oil-sector revenue includes corporate income tax receipts from EGPC and foreign partners, royalties, extraordinary payments, excise taxes on petrol products, and dividends collected from EGPC. 
Table 3. Egypt: General Government Fiscal Operations 1/

\begin{tabular}{|c|c|c|c|c|c|c|c|c|c|}
\hline & \multirow[t]{2}{*}{$2003 / 04$} & \multirow[t]{2}{*}{$2004 / 05$} & \multirow[t]{2}{*}{$2005 / 06$} & \multirow{2}{*}{$\begin{array}{r}\text { 2006/07 } \\
\text { Prel. 2/ }\end{array}$} & \multicolumn{2}{|c|}{$2007 / 08$} & \multirow{2}{*}{$\begin{array}{r}\text { 2008/09 } \\
\text { Proj. }\end{array}$} & \multirow{2}{*}{$\begin{array}{r}\text { 2009/10 } \\
\text { Proj. }\end{array}$} & \multirow{2}{*}{$\begin{array}{r}2010 / 11 \\
\text { Proj }\end{array}$} \\
\hline & & & & & Budget & Proj. & & & \\
\hline & \multicolumn{9}{|c|}{ (In billion Egyptian pounds) } \\
\hline Total revenue & 124.2 & 133.6 & 176.5 & 202.9 & 225.1 & 221.0 & 257.9 & 291.3 & 330.1 \\
\hline Tax revenue & 67.1 & 75.8 & 97.8 & 113.6 & 120.8 & 123.6 & 147.4 & 167.6 & 191.1 \\
\hline Income and property & 28.1 & 32.6 & 49.5 & 59.1 & 57.6 & 61.0 & 74.9 & 84.2 & 95.1 \\
\hline Goods and services & 26.6 & 31.4 & 34.7 & 39.9 & 45.7 & 46.2 & 53.8 & 61.8 & 70.9 \\
\hline International trade taxes & 9.2 & 7.7 & 9.7 & 10.4 & 13.3 & 11.5 & 13.0 & 15.0 & 17.5 \\
\hline Other taxes & 3.3 & 4.0 & 3.9 & 4.3 & 4.2 & 4.9 & 5.7 & 6.6 & 7.6 \\
\hline Nontax revenue & 52.0 & 55.0 & 76.3 & 85.8 & 101.1 & 94.2 & 107.3 & 120.3 & 135.4 \\
\hline Of which: mobile license fee & 0.0 & 0.0 & 0.0 & 15.3 & 5.2 & 5.2 & 0.0 & 0.0 & 0.0 \\
\hline Grants & 5.1 & 2.9 & 2.4 & 3.5 & 3.2 & 3.2 & 3.2 & 3.4 & 3.6 \\
\hline Expenditure & 153.6 & 171.4 & 224.2 & 240.9 & 263.7 & 273.6 & 311.9 & 338.5 & 365.8 \\
\hline Compensation to employees & 37.6 & 42.0 & 47.3 & 52.1 & 61.0 & 61.0 & 74.5 & 85.9 & 98.8 \\
\hline Purchases of goods and services & 9.4 & 12.7 & 14.5 & 16.1 & 17.0 & 17.2 & 20.0 & 23.1 & 26.5 \\
\hline Interest & 27.8 & 30.4 & 35.3 & 39.5 & 41.3 & 41.8 & 44.8 & 50.5 & 55.2 \\
\hline Subsidies, grants and social benefits $2 /$ & 34.9 & 41.2 & 86.1 & 88.7 & 93.6 & 108.9 & 136.4 & 152.4 & 171.0 \\
\hline Of which: fuel subsidy & & & 41.8 & 40.1 & 36.6 & 47.0 & 62.1 & 67.4 & 74.1 \\
\hline Other current expenditure & 21.1 & 21.7 & 19.8 & 20.6 & 22.9 & 23.0 & 26.7 & 30.8 & 35.5 \\
\hline Investment expenditure & 22.9 & 23.3 & 21.2 & 23.9 & 27.7 & 27.2 & 31.8 & 37.3 & 44.4 \\
\hline Measures $3 /$ & 0.0 & 0.0 & 0.0 & 0.0 & 0.0 & -5.7 & -22.3 & -41.6 & -65.7 \\
\hline Cash balance & -29.4 & -37.9 & -47.7 & -38.0 & -38.5 & -52.5 & -54.0 & -47.2 & -35.7 \\
\hline Net acquisition of financial assets & 10.7 & 7.4 & 8.9 & 18.1 & 7.3 & 5.8 & 6.4 & 7.1 & 7.8 \\
\hline \multirow[t]{2}{*}{ Overall balance } & -40.1 & -45.3 & -56.6 & -56.0 & -45.8 & -58.3 & -60.4 & -54.3 & -43.5 \\
\hline & \multicolumn{9}{|c|}{ (In percent of GDP) } \\
\hline Total revenue & 25.6 & 24.8 & 28.6 & 27.8 & 26.7 & 26.0 & 26.1 & 25.6 & 25.2 \\
\hline Tax revenue & 13.8 & 14.1 & 15.8 & 15.5 & 14.4 & 14.6 & 14.9 & 14.7 & 14.6 \\
\hline Income and property & 5.8 & 6.1 & 8.0 & 8.1 & 6.8 & 7.2 & 7.6 & 7.4 & 7.2 \\
\hline Goods and services & 5.5 & 5.8 & 5.6 & 5.5 & 5.4 & 5.4 & 5.4 & 5.4 & 5.4 \\
\hline International trade taxes & 1.9 & 1.4 & 1.6 & 1.4 & 1.6 & 1.4 & 1.3 & 1.3 & 1.3 \\
\hline Other taxes & 0.7 & 0.7 & 0.6 & 0.6 & 0.5 & 0.6 & 0.6 & 0.6 & 0.6 \\
\hline Nontax revenue & 10.7 & 10.2 & 12.4 & 11.7 & 12.0 & 11.1 & 10.9 & 10.6 & 10.3 \\
\hline Of which: mobile license fee & 0.0 & 0.0 & 0.0 & 2.1 & 0.6 & 0.6 & 0.0 & 0.0 & 0.0 \\
\hline Grants & 1.0 & 0.5 & 0.4 & 0.5 & 0.4 & 0.4 & 0.3 & 0.3 & 0.3 \\
\hline Expenditure & 31.7 & 31.8 & 36.3 & 32.9 & 31.3 & 32.2 & 31.6 & 29.7 & 27.9 \\
\hline Compensation to employees & 7.8 & 7.8 & 7.7 & 7.1 & 7.3 & 7.2 & 7.5 & 7.5 & 7.5 \\
\hline Purchases of goods and services & 1.9 & 2.4 & 2.3 & 2.2 & 2.0 & 2.0 & 2.0 & 2.0 & 2.0 \\
\hline Interest & 5.7 & 5.7 & 5.7 & 5.4 & 4.9 & 4.9 & 4.5 & 4.4 & 4.2 \\
\hline Subsidies, grants, and social benefits $2 /$ & 7.2 & 7.7 & 13.9 & 12.1 & 11.1 & 12.8 & 13.8 & 13.4 & 13.0 \\
\hline Of which: fuel subsidy & & & 7 & 5 & 4 & 6 & 6 & 6 & 6 \\
\hline Other current expenditure & 4.3 & 4.0 & 3.2 & 2.8 & 2.7 & 2.7 & 2.7 & 2.7 & 2.7 \\
\hline Investment expenditure & 4.7 & 4.3 & 3.4 & 3.3 & 3.3 & 3.2 & 3.2 & 3.3 & 3.4 \\
\hline Measures (cumulative) $3 /$ & 0.0 & 0.0 & 0.0 & 0.0 & 0.0 & -0.7 & -2.3 & -3.7 & -5.0 \\
\hline Cash balance & -6.1 & -7.0 & -7.7 & -5.2 & -4.6 & -6.2 & -5.5 & -4.1 & -2.7 \\
\hline Net acquisition of financial assets & 2.2 & 1.4 & 1.4 & 2.5 & 0.9 & 0.7 & 0.6 & 0.6 & 0.6 \\
\hline Overall balance & -8.3 & -8.4 & -9.2 & -7.7 & -5.4 & -6.9 & -6.1 & -4.8 & -3.3 \\
\hline Statistical discrepancy & -0.9 & -1.1 & -1.5 & 0.0 & 0.0 & 0.0 & 0.0 & 0.0 & 0.0 \\
\hline Financing sources & 7.4 & 7.3 & 7.7 & 7.6 & 5.4 & 6.9 & 6.1 & 4.8 & 3.3 \\
\hline Net domestic financing & 6.6 & 8.7 & 8.3 & 7.4 & 6.5 & 6.3 & 5.8 & 4.4 & 3.0 \\
\hline Net external financing & 0.1 & -0.8 & 0.6 & 0.5 & 0.3 & 0.3 & 0.3 & 0.3 & 0.3 \\
\hline Other, of which: & 0.7 & -0.6 & -1.2 & -0.3 & -1.4 & 0.3 & 0.0 & 0.0 & 0.0 \\
\hline Net privatization proceeds & 0.0 & 0.2 & 0.0 & 0.0 & 0.1 & 0.1 & 0.0 & 0.0 & 0.0 \\
\hline \multicolumn{10}{|l|}{ Memorandum items: } \\
\hline Overall balance net of one-off items $4 /$ & -8.3 & -8.4 & -11.4 & -8.7 & -5.8 & -7.3 & -6.1 & -4.8 & -3.3 \\
\hline Primary fiscal balance & -2.5 & -2.8 & -3.4 & -2.3 & -0.5 & -1.9 & -1.6 & -0.3 & 0.9 \\
\hline Oil-related revenue $5 /$ & 0.6 & 0.9 & 7.8 & 5.5 & 5.2 & 5.8 & 6.5 & 6.1 & 5.9 \\
\hline General government gross debt $6 /$ & 112.9 & 112.8 & 98.8 & 88.5 & 82.3 & 83.1 & 77.5 & 72.0 & 65.8 \\
\hline General government net debt 6/ & 82.4 & 80.5 & 79.8 & 72.6 & 68.5 & 69.4 & 65.8 & 61.8 & 57.0 \\
\hline Nominal GDP (in billion LE) & 485.3 & 538.5 & 617.7 & 731.2 & 841.7 & 849.0 & 987.4 & $1,139.2$ & $1,311.8$ \\
\hline
\end{tabular}

Sources: Ministry of Finance, Central Bank of Egypt

1/ General government includes the budget sector, the national investment bank (NIB), and social insurance funds. The fiscal year begins on July 1 . The data are presented on a cash basis consistent with the GFS 2001 classification.

2/ Beginning in 2005/06, the cost of domestic fuel subsidies covered by EGPC are recorded on-budget, with a corresponding counter-entry as notional revenues from EGPC.

3/ Measures yet to be implemented - e.g. sales tax reform (approx. 2-2.5 percent of GDP), energy subsidy cuts for industry (approx. 1.5 percent of GDP when fully in place), and fuel subsidy cuts

4/ Adjusted for one-off receipts from FY2005/06 onward, including the sale of Egypt Telecom, mobile license fee, and other.

5/ Oil-sector revenue includes corporate income tax receipts from EGPC and foreign partners, royalties, extraordinary payments, excise taxes on petrol products, and dividends collected from EGPC.

$6 /$ Includes domestic debt of the general government and external public and publicly guaranteed debt. 
Table 4. Egypt: Medium-Term Macroeconomic Framework, Baseline Scenario, 2003/04-2011/12

\begin{tabular}{|c|c|c|c|c|c|c|c|c|c|}
\hline & & & \multirow{2}{*}{$\begin{array}{l}\text { Act. } \\
\text { 2005/06 }\end{array}$} & \multirow{2}{*}{$\begin{array}{l}\text { Prel. Act. } \\
2006 / 07\end{array}$} & \multicolumn{5}{|c|}{ Projections } \\
\hline & $2003 / 04$ & $2004 / 05$ & & & $2007 / 08$ & 2008/09 & $2009 / 10$ & $2010 / 11$ & $2011 / 12$ \\
\hline & \multicolumn{9}{|c|}{ (In percent of GDP, unless otherwise indicated) } \\
\hline Real GDP (annual percent change) & 4.1 & 4.5 & 6.8 & 7.1 & 7.3 & 7.4 & 7.2 & 7.5 & 7.8 \\
\hline Hydrocarbon production & 2.4 & 0.6 & 21.2 & 6.3 & 5.2 & 5.2 & 0.7 & 2.7 & 4.8 \\
\hline Nonhydrocarbon production & 4.4 & 4.9 & 5.8 & 7.1 & 7.5 & 7.6 & 7.8 & 7.9 & 8.1 \\
\hline $\mathrm{CPI}$ inflation (average, annual percent change) & 8.1 & 8.8 & 4.2 & 10.9 & 7.8 & 8.0 & 7.8 & 7.2 & 6.7 \\
\hline Investment & 16.9 & 18.0 & 18.7 & 22.2 & 23.0 & 24.0 & 24.7 & 25.3 & 26.0 \\
\hline Private investment & 12.2 & 13.6 & 15.3 & 18.9 & 19.8 & 20.8 & 21.4 & 21.9 & 22.6 \\
\hline General government investment & 4.7 & 4.3 & 3.4 & 3.3 & 3.2 & 3.2 & 3.3 & 3.4 & 3.4 \\
\hline Savings & 21.3 & 21.2 & 19.5 & 23.5 & 23.8 & 23.6 & 23.5 & 23.6 & 23.8 \\
\hline Private savings & 22.6 & 23.9 & 23.8 & 25.5 & 26.8 & 25.9 & 24.4 & 22.9 & 23.2 \\
\hline General government savings & -1.3 & -2.7 & -4.3 & -1.9 & -3.0 & -2.2 & -0.9 & 0.7 & 0.7 \\
\hline External current account balance & 4.3 & 3.2 & 0.8 & 1.4 & 0.8 & -0.4 & -1.1 & -1.7 & -2.2 \\
\hline Overall fiscal balance (central government) & -9.5 & -9.6 & -8.2 & -7.5 & -7.0 & -5.7 & -4.4 & -3.0 & -3.0 \\
\hline Total public debt (net) & 82.4 & 80.5 & 79.8 & 72.6 & 69.4 & 65.8 & 61.8 & 57.0 & 52.8 \\
\hline Memorandum items: & \multicolumn{9}{|c|}{ Low-growth scenario 1/ } \\
\hline Real GDP (annual percent change) & 4.1 & 4.5 & 6.8 & 7.1 & 7.3 & 5.5 & 4.8 & 4.3 & 4.0 \\
\hline Investment & 16.9 & 18.0 & 18.7 & 22.2 & 22.8 & 22.4 & 21.7 & 20.8 & 20.0 \\
\hline Savings & 21.3 & 21.2 & 19.5 & 23.5 & 23.3 & 22.1 & 21.0 & 20.0 & 19.2 \\
\hline External current account balance & 4.3 & 3.2 & 0.8 & 1.4 & 0.5 & -0.3 & -0.7 & -0.8 & -0.8 \\
\hline Overall fiscal balance (central government) & -9.5 & -9.6 & -8.2 & -7.5 & -7.5 & -8.1 & -8.2 & -9.0 & -9.7 \\
\hline Total public debt (net) & 82.4 & 80.5 & 79.8 & 72.6 & 70.4 & 70.2 & 71.6 & 74.2 & 77.7 \\
\hline
\end{tabular}

Sources: Egyptian authorities; and Fund staff estimates and projections.

1/ The low-growth scenario assumes a relaxation of the reform and fiscal adjustment effort, leading to lower growth and worse debt dynamics compared to the baseline. 
Table 5. Egypt: Monetary Survey, 2003/04-2007/08

\begin{tabular}{|c|c|c|c|c|c|}
\hline & $2003 / 04$ & $\begin{array}{l}\text { 2004/05 } \\
\text { Act. }\end{array}$ & $2005 / 06$ & $\begin{array}{r}2006 / 07 \\
\text { Prel. Est. }\end{array}$ & $\begin{array}{r}2007 / 08 \\
\text { Proj. }\end{array}$ \\
\hline & \multicolumn{5}{|c|}{ (End-period stocks, in billions of Egyptian pounds) } \\
\hline Net foreign assets & 45.3 & 81.1 & 133.6 & 218.7 & 272.6 \\
\hline Net international reserves & 123.7 & 152.4 & 201.6 & 283.4 & 336.8 \\
\hline Central bank & 88.3 & 108.7 & 129.5 & 160.1 & 193.7 \\
\hline Other banks & 35.4 & 43.6 & 72.1 & 123.3 & 143.1 \\
\hline CBE medium- and long-term liabilities & -6.1 & -5.8 & -3.9 & -2.0 & -1.5 \\
\hline Blocked accounts (Rescheduled loans) 1/ & -72.3 & -65.5 & -64.0 & -62.7 & -62.7 \\
\hline Net domestic assets & 389.6 & 412.7 & 426.7 & 444.0 & 501.3 \\
\hline Net claims on government sector & 118.7 & 153.2 & 175.6 & 174.6 & 193.1 \\
\hline Claims on public sector companies & 35.6 & 37.4 & 32.9 & 24.4 & 21.0 \\
\hline Claims on private sector companies & 260.1 & 269.5 & 292.5 & 328.5 & 370.6 \\
\hline Net other items & -24.8 & -47.3 & -74.2 & -83.5 & -83.5 \\
\hline Broad money (M2) & 434.9 & 493.9 & 560.4 & 662.7 & 773.9 \\
\hline Domestic currency component (M2D) & 311.4 & 373.3 & 424.0 & 508.7 & 595.6 \\
\hline Foreign currency component & 123.6 & 120.6 & 136.4 & 154.0 & 178.3 \\
\hline \multicolumn{6}{|l|}{ Memorandum items: } \\
\hline \multicolumn{6}{|l|}{ Summary central bank balance sheet } \\
\hline Reserve money $2 / 3 /$ & 93.4 & 105.9 & 116.0 & 134.1 & 158.4 \\
\hline \multicolumn{6}{|l|}{ Other liabilities } \\
\hline Deposit auctions, CBE notes & 10.9 & 36.4 & 95.1 & 169.9 & \\
\hline Required reserves on foreign currency deposits & 45.1 & 33.6 & 16.4 & 17.7 & \\
\hline Net international reserves & 88.3 & 108.7 & 129.5 & 160.1 & 193.7 \\
\hline \multirow[t]{2}{*}{ Net domestic assets } & 75.3 & 102.6 & 98.1 & 162.2 & 183.1 \\
\hline & \multicolumn{5}{|c|}{ (Annual percent change, unless otherwise indicated) } \\
\hline Broad money (M2) & 13.2 & 13.6 & 13.5 & 18.3 & 16.8 \\
\hline Broad Money - Domestic currency component (M2D) 4/ & 11.5 & 19.9 & 13.6 & 20.0 & 17.1 \\
\hline Reserve money $5 /$ & 12.6 & 13.4 & 9.6 & 15.6 & 18.1 \\
\hline Reserve money 6/ & 8.8 & 0.7 & -5.0 & 14.4 & 17.4 \\
\hline Money multiplier (ratio) 7/ & 3.3 & 3.5 & 3.7 & 3.8 & 3.8 \\
\hline Contribution to Broad Money Growth & 13.2 & 13.6 & 13.5 & 18.3 & 16.8 \\
\hline NFA component & 5.1 & 8.2 & 10.6 & 15.2 & 8.1 \\
\hline NDA component & 8.0 & 5.3 & 2.8 & 3.1 & 8.6 \\
\hline Private sector credit $8 /$ & 4.5 & 3.6 & 8.6 & 12.3 & 12.8 \\
\hline in percent of GDP & 53.6 & 50.0 & 47.4 & 44.9 & 43.7 \\
\hline Government credit & 23.9 & 29.1 & 14.6 & -0.6 & 10.6 \\
\hline Domestic currency velocity (M2D/GDP) & 1.56 & 1.44 & 1.46 & 1.44 & 1.43 \\
\hline $\mathrm{M} 2$ velocity (M2/GDP) & 1.12 & 1.09 & 1.10 & 1.10 & 1.10 \\
\hline Dollarization $10 /$ & 28.4 & 24.4 & 24.3 & 23.2 & $\ldots$ \\
\hline
\end{tabular}

Sources: Central Bank of Egypt; and IMF staff estimates and projections.

1/ Payments (on original schedule) of public enterprises on debt rescheduled by the Paris Club.

2/ Excludes deposit auctions.

3/ Excludes reserve requirements on foreign currency deposits.

4/ Broad money less foreign currency deposits.

5/ Excludes foreign currency deposits of commercial banks at the CBE.

6/ Includes foreign currency deposits of commercial banks at the CBE.

7/ Ratio of broad money (domestic currency component) to reserve money excluding foreign currency deposits.

8/ Excluding public sector companies. Starting in 2004/05, the growth rate of private credit is reportedly biased downward by large repayments on nonperforming loans in the context of the banking sector restructuring.

9/ Excludes valuation effects.

10/ Foreign currency deposits in percent of broad money. 
Table 6. Egypt: Medium-Term Balance of Payments, 2003/04-2011/12

\begin{tabular}{|c|c|c|c|c|c|c|c|c|c|}
\hline & & & & \multirow{2}{*}{$\begin{array}{l}\text { Est. } \\
2006 / 07\end{array}$} & \multicolumn{5}{|c|}{ Projections } \\
\hline & $2003 / 04$ & $2004 / 05$ & $2005 / 06$ & & $2007 / 08$ & $2008 / 09$ & $2009 / 10$ & $2010 / 11$ & $2011 / 12$ \\
\hline & \multicolumn{8}{|c|}{ (billions of U.S. dollars, unless otherwise indicated) } & \\
\hline Current account balance & 3.4 & 2.9 & 0.9 & 1.8 & 1.2 & -0.6 & -2.2 & -3.6 & -5.0 \\
\hline Trade balance & -7.8 & -10.4 & -12.0 & -15.8 & -19.5 & -22.4 & -25.5 & -28.6 & -31.8 \\
\hline Exports & 10.5 & 13.8 & 18.5 & 22.0 & 26.2 & 28.6 & 30.8 & 34.0 & 37.8 \\
\hline Of which: oil & 3.9 & 5.0 & 7.4 & 7.4 & 8.5 & 8.0 & 7.4 & 7.0 & 6.6 \\
\hline Gas & 0.0 & 0.3 & 2.8 & 2.7 & 2.9 & 3.1 & 3.1 & 3.7 & 4.2 \\
\hline Imports & -18.3 & -24.2 & -30.4 & -37.8 & -45.6 & -50.9 & -56.3 & -62.6 & -69.6 \\
\hline Of which: oil & -2.6 & -4.0 & -5.4 & -4.1 & -5.0 & -5.1 & -5.1 & -5.2 & -5.4 \\
\hline Services (net) & 7.3 & 7.8 & 7.3 & 10.5 & 12.1 & 12.6 & 13.6 & 14.6 & 15.7 \\
\hline Receipts & 13.0 & 15.0 & 16.6 & 19.5 & 21.9 & 24.2 & 26.2 & 28.3 & 30.6 \\
\hline Of which: Tourism & 5.5 & 6.4 & 6.4 & 7.1 & 7.8 & 8.6 & 9.2 & 10.0 & 10.8 \\
\hline Suez canal dues & 2.8 & 3.3 & 3.6 & 4.2 & 4.6 & 4.9 & 5.3 & 5.6 & 6.0 \\
\hline Investment income & 0.5 & 0.9 & 2.0 & 3.0 & 3.8 & 4.3 & 4.6 & 4.8 & 5.0 \\
\hline Payments & 5.7 & 7.2 & 9.2 & 9.0 & 9.7 & 11.5 & 12.6 & 13.7 & 14.9 \\
\hline Interest payments & 0.6 & 0.6 & 0.6 & 0.6 & 0.6 & 1.2 & 1.2 & 1.3 & 1.3 \\
\hline Profit remittances & 0.1 & 0.6 & 0.9 & 1.3 & 1.3 & 1.8 & 2.1 & 2.4 & 2.7 \\
\hline Travel payments & 1.3 & 1.4 & 1.6 & 1.9 & 2.1 & 2.4 & 2.7 & 3.0 & 3.3 \\
\hline Transfers & 3.9 & 5.4 & 5.5 & 7.1 & 8.5 & 9.1 & 9.7 & 10.4 & 11.1 \\
\hline Official grants & 0.9 & 1.1 & 0.6 & 0.8 & 0.7 & 0.6 & 0.6 & 0.6 & 0.6 \\
\hline Private remittances & 3.0 & 4.4 & 5.0 & 6.3 & 7.8 & 8.5 & 9.1 & 9.8 & 10.5 \\
\hline Capital account & -1.7 & 2.1 & 4.6 & 4.3 & 4.7 & 5.1 & 6.2 & 7.3 & 7.3 \\
\hline Medium- and long-term loans (net) & -0.6 & -1.3 & 1.5 & -0.6 & -0.7 & -0.8 & -0.4 & -0.4 & -0.7 \\
\hline Drawings & 1.3 & 0.8 & 4.2 & 1.4 & 1.5 & 1.8 & 1.9 & 2.0 & 2.4 \\
\hline Government market borrowing & 0.0 & 0.0 & 2.8 & 0.0 & 0.5 & 0.5 & 0.5 & 0.6 & 1.0 \\
\hline Other $1 /$ & 1.3 & 0.8 & 1.4 & 1.4 & 1.0 & 1.3 & 1.4 & 1.4 & 1.4 \\
\hline Amortization & -1.9 & -2.1 & -2.7 & -1.9 & -2.2 & -2.6 & -2.3 & -2.4 & -3.1 \\
\hline FDI $2 /$ & 2.6 & 3.9 & 6.0 & 10.5 & 8.3 & 6.5 & 6.8 & 7.2 & 7.5 \\
\hline Portfolio investment & -0.1 & 1.4 & 2.1 & 3.7 & 0.6 & 0.6 & 0.6 & 0.5 & 0.5 \\
\hline Commercial banks' NFA & -3.5 & -1.8 & -5.0 & -9.1 & -3.5 & -1.2 & -0.8 & 0.0 & 0.0 \\
\hline Other (including short-term capital) & 0.0 & 0.0 & 0.0 & -0.2 & 0.0 & 0.0 & 0.0 & 0.0 & 0.0 \\
\hline Errors and omissions (net) $3 /$ & -1.9 & -0.5 & -2.3 & -0.7 & 0.0 & 0.0 & 0.0 & 0.0 & 0.0 \\
\hline Overall balance & -0.2 & 4.5 & 3.2 & 5.3 & 5.9 & 4.4 & 4.0 & 3.7 & 2.3 \\
\hline Of which: net international reserves & 0.2 & -4.5 & -3.2 & -5.3 & -5.9 & -4.4 & -4.0 & -3.7 & -2.3 \\
\hline \multicolumn{10}{|l|}{ Memorandum items: } \\
\hline Current account (percent of GDP) & 4.3 & 3.2 & 0.8 & 1.4 & 0.8 & -0.4 & -1.1 & -1.7 & -2.2 \\
\hline Oil trade balance (percent of GDP) & 1.7 & 1.2 & 1.9 & 2.6 & 2.3 & 1.7 & 1.2 & 0.8 & 0.5 \\
\hline Gross reserves (in US\$ billions, end of period) & 14.8 & 19.3 & 22.9 & 28.3 & 34.2 & 38.6 & 42.7 & 46.4 & 48.6 \\
\hline In months of next year imports of goods and services & 5.7 & 5.8 & 5.9 & 6.1 & 6.6 & 6.7 & 6.7 & 6.6 & 6.6 \\
\hline GDP (in US\$ billions) & 78.8 & 89.8 & 107.4 & 127.9 & 149.7 & 172.3 & 190.5 & 209.2 & 230.1 \\
\hline External debt $4 /$ & 29.9 & 28.9 & 30.9 & 30.9 & 30.2 & 29.4 & 29.0 & 28.6 & 27.9 \\
\hline External debt service (percent of exports GNFS) & 10.9 & 9.7 & 10.0 & 6.6 & 6.3 & 7.9 & 6.6 & 6.3 & 6.9 \\
\hline
\end{tabular}

Sources: Central Bank of Egypt; IMF staff estimates and projections.

$1 /$ Includes multilateral and bilateral public sector borrowing and private borrowing.

2/ Data before 2004/05 are the CBE data on non-oil FDI augmented by estimates of FDI in the oil and gas sector derived from EGPC annual reports.

$3 /$ In addition to the revisions to the FDI data (see footnote 2), IMF staff make four other adjustments to the official balance of payments data. First, the CBE estimates record the difference between a headcount-based estimate of tourism-related inflows and the estimates obtained from the International Transactions Recording System as an outflow in the capital account. The staff estimates here record only the flows based on direct estimates of tourists arrivals with the errors and omissions line offsetting any upward bias implicit in these estimates. Second, because of large discrepancies between the annual flows of net short-term suppliers credits and changes in end-of-period stocks in the official data, net flows of short-term suppliers credits are not identified here and are instead absorbed in errors and omissions. Third, unlike in the official data and in order to preserve symmetry with unrecorded capital outflows on account of currency substitution in earlier years, reverse currency substitution in 2004/05 is not recorded under other capital inflows, but reflected in errors and omissions instead. Fourth, unlike the official data, changes in nonresident holdings of domestic currency-denominated treasury bills are recorded under portfolio investment (US $\$ 2.9$ billion in $2005 / 06$ al 4/ The official data on external debt do not include nonresident holdings of domestic currency-denominated treasury bills (about US $\$ 8.1$ billion at end-June 2007 ). 
Table 7. Egypt: Selected Vulnerability Indicators, 2003/04-2007/08

\begin{tabular}{|c|c|c|c|c|c|}
\hline & $2003 / 04$ & $2004 / 05$ & $2005 / 06$ & 2006/07 & 2007/08 \\
\hline \multicolumn{6}{|l|}{ Key economic and market indicators } \\
\hline Real GDP growth (percent) & 4.1 & 4.5 & 6.8 & 7.1 & 7.3 \\
\hline CPI inflation (period average, percent) & 8.1 & 8.8 & 4.2 & 10.9 & 7.8 \\
\hline Short-term interest rate (91-day Treasury bill rate, percent) & 8.4 & 10.2 & 8.8 & 8.7 & $\ldots$ \\
\hline Five-year eurobond spread (basis points, over U.S. Treasury) & 122 & 92 & 64 & 194 & $\ldots$ \\
\hline Exchange rate (LE per dollar, end-of-period) & 6.20 & 5.78 & 5.76 & 5.70 & $\ldots$ \\
\hline \multicolumn{6}{|l|}{ External sector } \\
\hline Exchange rate regime & \multicolumn{5}{|c|}{ De jure managed float; de facto float since mid-2007 } \\
\hline Current account balance (percent of GDP) & 4.3 & 3.2 & 0.8 & 1.4 & 0.8 \\
\hline Net FDI inflows (percent of GDP) & 3.2 & 4.3 & 5.6 & 8.2 & 5.5 \\
\hline Exports (percentage change of US\$ value, GNFS) & 27.5 & 21.8 & 18.1 & 16.5 & 15.0 \\
\hline Real effective exchange rate $(1991=100)$ & 95.8 & 99.8 & 107.9 & 112.6 & $\ldots$ \\
\hline Gross international reserves (GIR) (US\$ billions) & 14.8 & 19.3 & 22.9 & 28.3 & 34.2 \\
\hline GIR in percent of debt at remaining maturity $1 /$ & 437 & 486 & 529 & 794 & 899 \\
\hline GIR in percent of debt at remaining maturity and banks' FX deposits 1/ & 136.6 & 114.6 & 127.7 & 128.4 & 139.3 \\
\hline Net international reserves (US\$ billions) & 14.8 & 19.3 & 22.9 & 28.3 & 34.2 \\
\hline Total gross external debt in percent of GDP & 37.9 & 32.2 & 28.8 & 24.2 & 20.2 \\
\hline Of which: short-term external debt (original maturity, percent of total) & 0.7 & 0.3 & 0.4 & 0.4 & 1.8 \\
\hline external debt of domestic private sector (percent of total) & 4.9 & 4.7 & 6.3 & 5.2 & 6.6 \\
\hline Total gross external debt in percent of exports of GNFS & 130.2 & 103.6 & 93.6 & 80.4 & 68.4 \\
\hline Gross external financing requirement (US\$ billions) 2/ & -1.5 & -0.8 & 1.8 & 0.2 & 1.0 \\
\hline \multicolumn{6}{|l|}{ Public sector $3 /$} \\
\hline General government balance (percent of GDP) & -8.3 & -8.4 & -9.2 & -7.7 & -6.9 \\
\hline Primary balance (Central government; percent of GDP) & -3.1 & -3.5 & -2.2 & -0.9 & -0.9 \\
\hline Public sector gross debt (percent of GDP) & 112.9 & 112.8 & 98.8 & 88.5 & 83.1 \\
\hline Public sector net debt (percent of GDP) & 82.4 & 80.5 & 79.8 & 72.6 & 69.4 \\
\hline \multicolumn{6}{|l|}{ Banking sector $4 /$} \\
\hline Capital adequacy ratio (percent) & 11.1 & 13.8 & 14.5 & $\ldots$ & $\ldots$ \\
\hline NPLs as percent of total loans & 24.2 & 26.3 & 25.0 & $\ldots$ & $\ldots$ \\
\hline Provisions as percent of NPLs & 57.0 & 53.1 & 54.9 & $\ldots$ & $\ldots$ \\
\hline Return on average assets (percent) & 0.5 & 0.6 & 0.6 & $\ldots$ & $\ldots$ \\
\hline Return on equity (percent) & 9.8 & 10.6 & 10.7 & $\ldots$ & $\ldots$ \\
\hline FX deposits (percent of total deposits) & 32.6 & 28.0 & 28.0 & $\ldots$ & $\ldots$ \\
\hline FX loans (percent of total loans) & 28.4 & 24.4 & 24.3 & $\ldots$ & $\ldots$ \\
\hline Government debt held by financial sector (percent of total assets) & 43.8 & 45.2 & 44.4 & $\ldots$ & $\ldots$ \\
\hline Credit to private sector (percent change) & 4.5 & 3.6 & 8.6 & 12.3 & 12.8 \\
\hline \multicolumn{6}{|l|}{ Memorandum item: } \\
\hline Nominal GDP (US\$ billions) & 78.8 & 89.8 & 107.4 & 127.9 & 149.7 \\
\hline
\end{tabular}

Sources: Egyptian authorities; and IMF staff estimates and projections.

1/ Debt at remaining maturity is defined as external short-term debt plus maturing medium- and long-term external debt.

2/ Current account deficit plus amortization of external debt.

3/ Public sector covers the general government.

4/ The banking sector includes commercial banks (public and private), business and investment banks, and specialized banks. 
Table 8. Egypt: Public Sector Debt Sustainability Framework, 2002/03-2012/13

(In percent of GDP, unless otherwise indicated)

\begin{tabular}{|c|c|c|c|c|c|c|c|c|c|c|c|c|}
\hline & \multicolumn{5}{|c|}{ Actual } & \multicolumn{6}{|c|}{ Projections } & \multirow[b]{2}{*}{$\begin{array}{l}\text { Debt-stabilizing } \\
\text { primary balance }\end{array}$} \\
\hline & $2002 / 03$ & 2003/04 & $2004 / 05$ & $2005 / 06$ & 2006/07 & $2007 / 08$ & $2008 / 09$ & $2009 / 10$ & 2010/11 & 2011/12 & 2012/13 & \\
\hline Baseline: Public sector debt 1/ & 85.9 & 82.4 & 80.5 & 79.8 & 72.6 & 69.4 & 65.8 & 61.8 & 57.0 & 52.8 & 49.1 & -2.6 \\
\hline Of which: foreign-currency denominated & 39.8 & 35.6 & 29.1 & 26.1 & 22.2 & 20.9 & 19.5 & 18.1 & 16.5 & 15.2 & 14.0 & \\
\hline Change in public sector debt & 8.8 & -3.5 & -1.9 & -0.7 & -7.2 & -3.2 & -3.6 & -4.0 & -4.8 & -4.2 & -3.7 & \\
\hline Identified debt-creating flows $(4+7+12)$ & 10.8 & -2.8 & -2.1 & -1.2 & -5.0 & -3.3 & -3.6 & -4.0 & -4.8 & -4.2 & -3.7 & \\
\hline Primary deficit & 3.3 & 2.5 & 2.8 & 3.4 & 2.3 & 1.9 & 1.6 & 0.3 & -0.9 & -0.6 & -0.3 & \\
\hline Revenue and grants & 26.2 & 25.6 & 24.8 & 28.6 & 27.8 & 26.0 & 26.1 & 25.6 & 25.2 & 24.8 & 24.6 & \\
\hline Primary (noninterest) expenditure & 29.5 & 28.1 & 27.6 & 32.0 & 30.0 & 28.0 & 27.7 & 25.9 & 24.3 & 24.3 & 24.3 & \\
\hline Automatic debt dynamics $2 /$ & 7.5 & -5.4 & -4.7 & -4.7 & -7.2 & -5.1 & -5.2 & -4.3 & -3.9 & -3.6 & -3.4 & \\
\hline Contribution from interest rate/growth differential $3 /$ & -1.4 & -6.3 & -2.5 & -4.6 & -7.0 & -5.1 & -5.2 & -4.3 & -3.9 & -3.6 & -3.4 & \\
\hline Of which: contribution from real interest rate & 0.8 & -3.3 & 0.8 & 0.2 & -2.2 & -0.6 & -0.8 & -0.2 & 0.1 & 0.2 & 0.2 & \\
\hline Of which: contribution from real GDP growth & -2.2 & -3.0 & -3.3 & -4.8 & -4.8 & -4.6 & -4.4 & -4.1 & -4.0 & -3.9 & -3.6 & \\
\hline Contribution from exchange rate depreciation $4 /$ & 8.9 & 0.9 & -2.2 & -0.1 & -0.2 & $\ldots$ & $\ldots$ & $\ldots$ & $\ldots$ & $\ldots$ & $\ldots$ & \\
\hline Other identified debt-creating flows & 0.0 & 0.0 & -0.2 & 0.0 & 0.0 & -0.1 & $\ldots$ & $\ldots$ & $\ldots$ & $\ldots$ & $\ldots$ & \\
\hline Privatization receipts (negative) & 0.0 & 0.0 & -0.2 & -0.2 & -1.4 & -1.2 & $\ldots$ & $\ldots$ & $\ldots$ & $\ldots$ & $\ldots$ & \\
\hline Recognition of implicit or contingent liabilities & 0.0 & 0.0 & 0.0 & 0.0 & 0.0 & 0.0 & $\ldots$ & $\ldots$ & $\ldots$ & $\ldots$ & $\ldots$ & \\
\hline Other (bank and SOE restructuring costs) & 0.0 & 0.0 & 0.0 & 0.2 & 1.3 & 1.1 & $\ldots$ & $\ldots$ & $\ldots$ & $\ldots$ & $\ldots$ & \\
\hline Residual, including asset changes $(2-3) 5 /$ & -2.0 & -0.7 & 0.3 & 0.6 & -2.3 & 0.1 & $\ldots$ & $\ldots$ & $\ldots$ & $\ldots$ & $\ldots$ & \\
\hline Public sector debt-to-revenue ratio $1 /$ & 328.3 & 321.8 & 324.7 & 279.5 & 261.7 & 266.6 & 251.9 & 241.6 & 226.5 & 212.5 & 199.7 & \\
\hline $\begin{array}{l}\text { Gross financing need } 6 \text { / } \\
\text { in billions of US dollars }\end{array}$ & $\begin{array}{l}26.5 \\
21.6\end{array}$ & $\begin{array}{l}26.7 \\
21.1\end{array}$ & $\begin{array}{l}27.0 \\
24.2\end{array}$ & $\begin{array}{l}26.7 \\
28.7\end{array}$ & $\begin{array}{l}24.5 \\
31.4\end{array}$ & $\begin{array}{l}22.5 \\
33.7\end{array}$ & $\begin{array}{l}21.0 \\
36.3\end{array}$ & $\begin{array}{l}19.0 \\
36.2\end{array}$ & $\begin{array}{l}16.7 \\
35.0\end{array}$ & $\begin{array}{l}15.7 \\
36.0\end{array}$ & $\begin{array}{l}14.7 \\
37.2\end{array}$ & \\
\hline Scenario with key variables at their historical averages 71 & & & & & & 69.4 & 69.4 & 69.4 & 69.4 & 69.4 & 69.5 & -2.3 \\
\hline Scenario with no policy change (constant primary balance) in $2008 / 09-2012 / 13$ & & & & & & 69.4 & 65.9 & 63.2 & 61.3 & 59.4 & 57.6 & -3.0 \\
\hline \multicolumn{13}{|l|}{ Key Macroeconomic and Fiscal Assumptions Underlying Baseline } \\
\hline Real GDP growth (in percent) & 3.2 & 4.1 & 4.5 & 6.8 & 7.1 & 7.3 & 7.4 & 7.2 & 7.5 & 7.8 & 7.8 & \\
\hline Average nominal interest rate on public debt (in percent) $8 /$ & 8.1 & 7.7 & 7.6 & 8.2 & 8.0 & 7.9 & 7.6 & 7.8 & 7.8 & 7.8 & 7.7 & \\
\hline Average real interest rate (nominal rate minus change in GDP deflator, in percent) & 1.3 & -3.9 & 1.4 & 0.8 & -2.5 & -0.3 & -0.7 & 0.1 & 0.7 & 1.0 & 1.0 & \\
\hline Nominal appreciation (increase in US dollar value of local currency, in percent) & -22.9 & -2.5 & 7.2 & 0.3 & 1.1 & $\ldots$ & & & $\ldots$ & & $\ldots$ & \\
\hline Inflation rate (GDP deflator, in percent) & 6.8 & 11.7 & 6.2 & 7.4 & 10.5 & 8.2 & 8.3 & 7.7 & 7.1 & 6.8 & 6.8 & \\
\hline Growth of real primary spending (deflated by GDP deflator, in percent) & 4.2 & -0.8 & 2.3 & 24.1 & 0.4 & 0.0 & 6.4 & 0.2 & 0.7 & 7.8 & 7.9 & \\
\hline
\end{tabular}

Sources: IMF staff estimates and projections.

$1 /$ Refers to the general government, including government guaranteed debt.

2/ Derived as $[(r-p(1+g)-g+a e(1+r)] /(1+g+p+g p))$ times previous period debt ratio, with $r=$ interest rate; $p=$ growth rate of GDP deflator; $g=$ real GDP growth rate; $a=$ share of foreign-currency denominated debt; and $\mathrm{e}=$ nominal exchange rate depreciation (measured by increase in local currency value of US dollar).

$3 /$ The real interest rate contribution is derived from the denominator in footnote $2 /$ as $r-\pi(1+g)$ and the real growth contribution as $-\mathrm{g}$.

$4 /$ The exchange rate contribution is derived from the numerator in footnote $2 /$ as ae( $1+r)$.

$5 /$ For projections, this line includes exchange rate changes.

$6 /$ Defined as public sector deficit, plus amortization of medium and long-term public sector debt, plus short-term debt at end of previous period.

7/ The key variables include real GDP growth; real interest rate; and primary balance in percent of GDP.

8/ Derived as nominal interest expenditure divided by previous period debt stock.

9/ Assumes that key variables (real GDP growth, real interest rate, and other identified debt-creating flows) remain at the level of the last projection year. 
Figure 3. Egypt: Public Debt Sustainability: Bound Tests 1/

(Net public debt in percent of GDP)

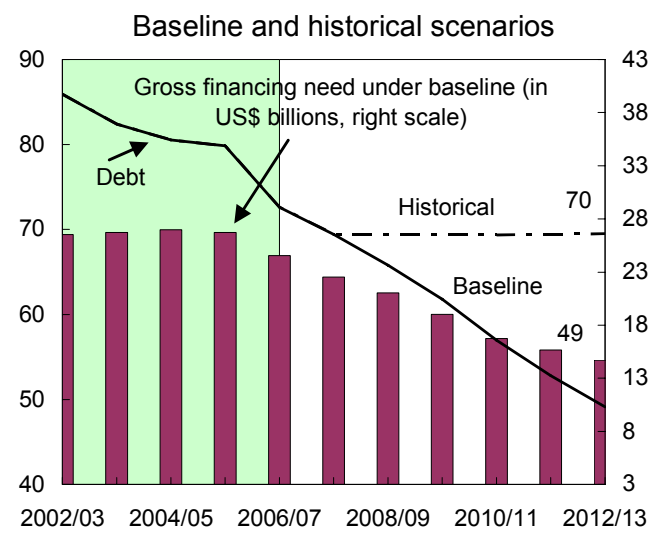

Real interest rate shock (in percent)
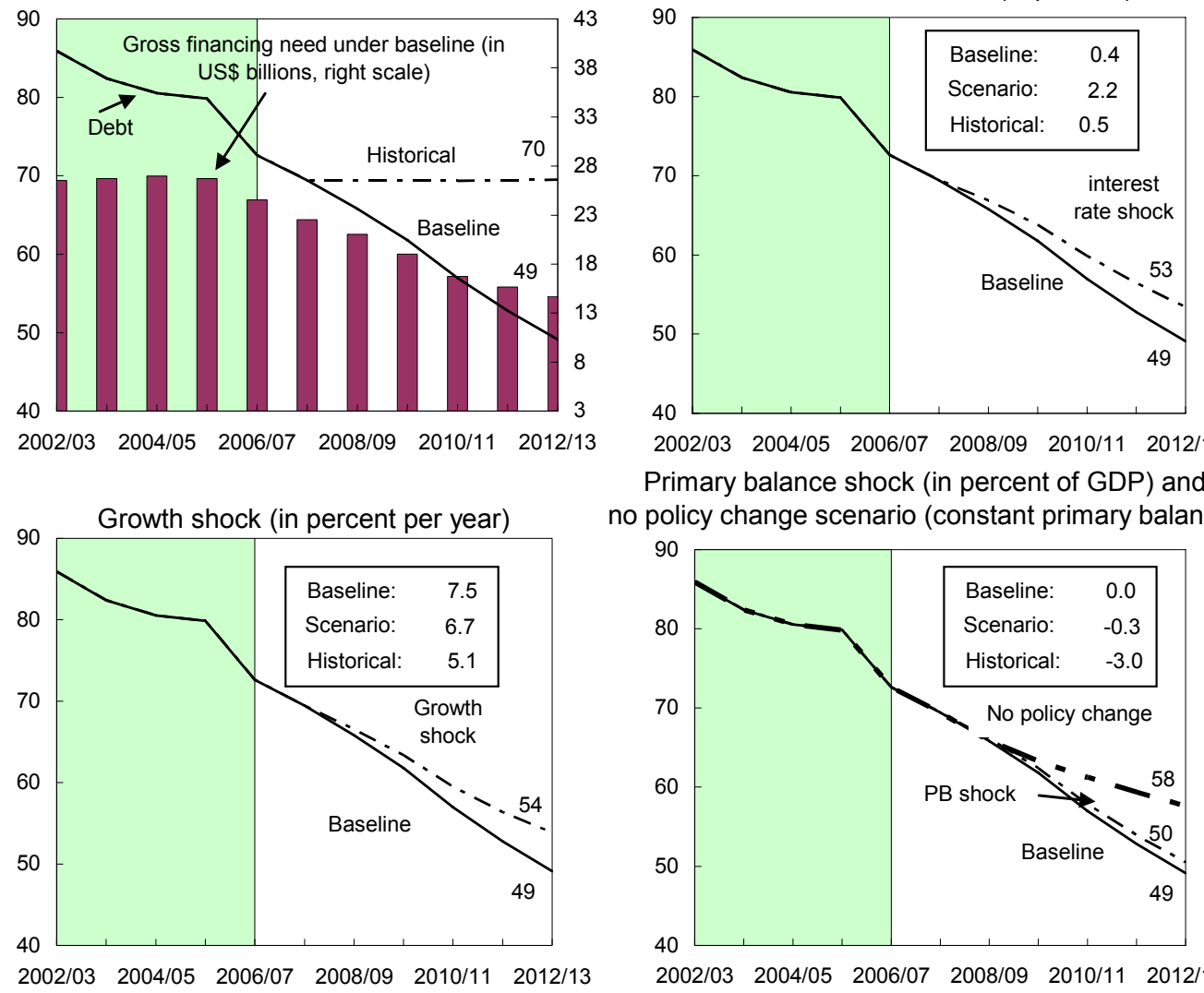

2002/03 2004/05 2006/07 2008/09 2010/11 2012/13

Primary balance shock (in percent of GDP) and no policy change scenario (constant primary balance)

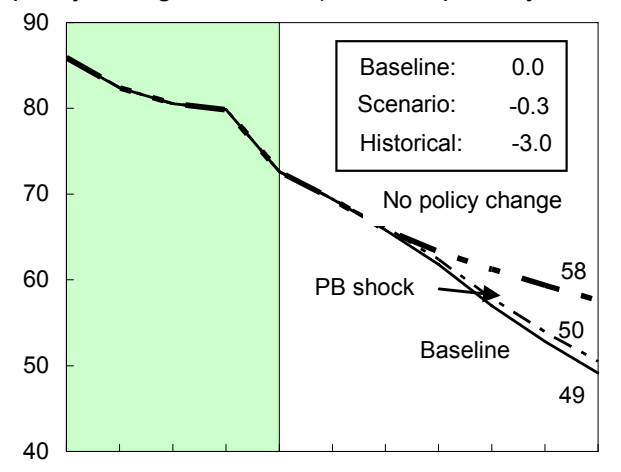

2002/03 2004/05 2006/07 2008/09 2010/11 2012/13

Combined shock $2 /$

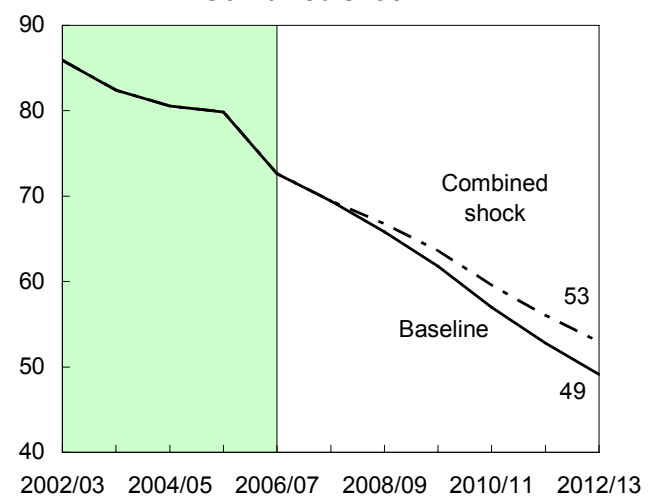

Real depreciation and contingent liabilities shocks $3 /$

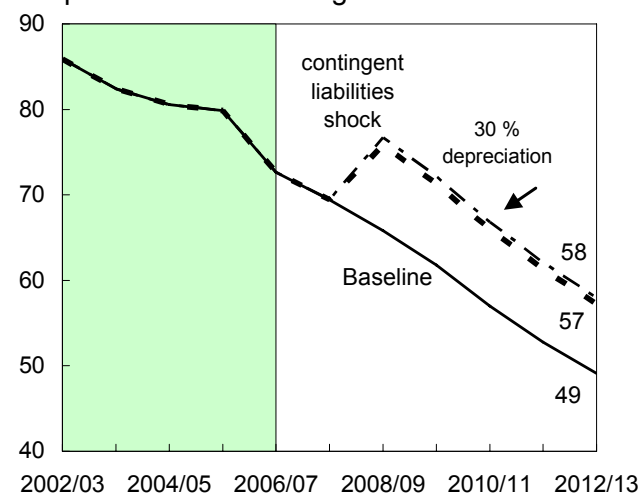

Sources: International Monetary Fund, country desk data, and staff estimates.

1/ Shaded areas represent actual data. Individual shocks are permanent one-half standard deviation shocks. Figures in the boxes represent average projections for the respective variables in the baseline and scenario being presented. Ten-year historical average for the variable is also shown.

2/ Permanent 1/4 standard deviation shocks applied to real interest rate, growth rate, and primary balance.

3/ One-time real depreciation of 30 percent and 10 percent of GDP shock to contingent liabilities occur in 2008, with real depreciation defined as nominal depreciation (measured by percentage fall in dollar value of local currency) minus domestic inflation (based on GDP deflator). 
Table 9. Egypt: External Debt Sustainability Framework, 2002/03-2012/13

(In percent of GDP, unless otherwise indicated)

\begin{tabular}{|c|c|c|c|c|c|c|c|c|c|c|c|c|}
\hline & \multicolumn{5}{|c|}{ Actual } & \multicolumn{7}{|c|}{$\begin{array}{c}\text { Projections } \\
\end{array}$} \\
\hline & $2002 / 03$ & $2003 / 04$ & $2004 / 05$ & $2005 / 06$ & $2006 / 07$ & $2007 / 08$ & $2008 / 09$ & $2009 / 10$ & $2010 / 11$ & $2011 / 12$ & $2012 / 13$ & \\
\hline Baseline: External debt & 36.1 & 37.9 & 32.2 & 28.8 & 24.2 & 20.2 & 17.1 & 15.2 & 13.7 & 12.1 & 11.1 & $\begin{array}{l}\text { Debt-stabilizing } \\
\text { non-interest }\end{array}$ \\
\hline Change in external debt & 3.4 & 1.8 & -5.7 & -3.5 & -4.6 & -4.0 & -3.1 & -1.8 & -1.5 & -1.6 & -1.1 & current account $6 /$ \\
\hline Identified external debt-creating flows $(4+8+9)$ & 0.6 & -11.6 & -13.3 & -14.3 & -17.5 & -8.5 & -5.3 & -4.1 & -3.2 & -2.4 & -1.6 & -4.1 \\
\hline Current account deficit, excluding interest payments & -3.2 & -5.1 & -3.9 & -1.4 & -1.8 & -1.2 & -0.3 & 0.5 & 1.1 & 1.6 & 2.2 & \\
\hline Deficit in balance of goods and services & 1.9 & 0.4 & 2.5 & 4.9 & 5.1 & 6.2 & 6.4 & 6.9 & 7.3 & 7.5 & 7.7 & \\
\hline Exports & 22.1 & 29.1 & 31.1 & 30.7 & 30.0 & 29.5 & 28.1 & 27.5 & 27.5 & 27.5 & 27.5 & \\
\hline Imports & 24.0 & 29.5 & 33.7 & 35.6 & 35.1 & 35.7 & 34.5 & 34.4 & 34.7 & 35.0 & 35.2 & \\
\hline Net nondebt creating capital inflows (negative) & -2.9 & -3.0 & -5.2 & -8.2 & -11.6 & -6.2 & -4.4 & -4.1 & -3.9 & -3.7 & -3.5 & \\
\hline Automatic debt dynamics $1 /$ & 6.7 & -3.6 & -4.2 & -4.7 & -4.1 & -1.1 & -0.6 & -0.5 & -0.4 & -0.4 & -0.4 & \\
\hline Contribution from nominal interest rate & 0.8 & 0.6 & 0.6 & 0.5 & 0.5 & 0.4 & 0.7 & 0.6 & 0.6 & 0.5 & 0.5 & \\
\hline Contribution from real GDP growth & -1.2 & -1.3 & -1.5 & -1.8 & -1.7 & -1.5 & -1.3 & -1.1 & -1.0 & -1.0 & -0.9 & \\
\hline Contribution from price and exchange rate changes $2 /$ & 7.0 & -2.9 & -3.3 & -3.4 & -2.9 & $\ldots$ & $\ldots$ & $\ldots$ & $\ldots$ & $\ldots$ & $\ldots$ & \\
\hline Residual, including change in gross foreign assets $(2-3) 3 /$ & 2.8 & 13.4 & 7.6 & 10.8 & 12.9 & 4.6 & 2.1 & 2.2 & 1.6 & 0.9 & 0.5 & \\
\hline External debt-to-exports ratio (in percent) & 163.3 & 130.2 & 103.6 & 93.6 & 80.4 & 68.4 & 60.7 & 55.3 & 49.8 & 44.0 & 40.2 & \\
\hline Gross external financing need (in billions of US dollars) $4 /$ & 1.3 & -0.1 & 0.7 & 3.7 & 1.8 & 2.6 & 4.9 & 6.1 & 7.6 & 9.8 & 10.7 & \\
\hline in percent of GDP & 1.6 & -0.2 & 0.8 & 3.4 & 1.4 & 1.7 & 2.9 & 3.2 & 3.6 & 4.2 & 4.2 & \\
\hline Scenario with key variables at their historical averages 5 / & & & & & & 20.2 & 18.5 & 17.2 & 16.1 & 14.8 & 14.1 & -4.6 \\
\hline \multicolumn{13}{|l|}{ Key macroeconomic assumptions underlying baseline } \\
\hline Real GDP growth (in percent) & 3.2 & 4.1 & 4.5 & 6.8 & 7.1 & 7.3 & 7.4 & 7.2 & 7.5 & 7.8 & 7.8 & \\
\hline GDP deflator in US dollars (change in percent) & -17.7 & 8.8 & 9.6 & 11.9 & 11.3 & 9.1 & 7.1 & 3.2 & 2.2 & 2.0 & 2.7 & \\
\hline Nominal external interest rate (in percent) & 2.2 & 2.0 & 2.0 & 2.0 & 1.9 & 2.0 & 3.9 & 4.1 & 4.4 & 4.4 & 4.6 & \\
\hline Growth of exports of goods and services (US dollar terms, in percent) & 14.0 & 27.5 & 21.8 & 18.1 & 16.5 & 15.0 & 9.6 & 8.1 & 9.7 & 10.4 & 10.7 & \\
\hline Growth of imports of goods and services (US dollar terms, in percent) & 0.2 & 18.8 & 30.0 & 26.5 & 17.6 & 18.9 & 11.3 & 10.2 & 10.8 & 11.0 & 11.3 & \\
\hline Current account balance, excluding interest payments & 3.2 & 5.1 & 3.9 & 1.4 & 1.8 & 1.2 & 0.3 & -0.5 & -1.1 & -1.6 & -2.2 & \\
\hline Net non-debt creating capital inflows & 2.9 & 3.0 & 5.2 & 8.2 & 11.6 & 6.2 & 4.4 & 4.1 & 3.9 & 3.7 & 3.5 & \\
\hline
\end{tabular}

$1 /$ Derived as $[r-g-r(1+g)+e a(1+r)] /(1+g+r+g r)$ times previous period debt stock, with $r=$ nominal effective interest rate on external debt; $r=$ change in domestic GDP deflator in US dollar terms, $g=$ real GDP growth rate, $e=$ nominal appreciation (increase in dollar value of domestic currency), and $a=$ share of domestic-currency denominated debt in total external debt.

$2 /$ The contribution from price and exchange rate changes is defined as $[-r(1+g)+e a(1+r)] /(1+g+r+g r)$ times previous period debt stock. $r$ increases with an appreciating domestic currency $(\mathrm{e}>0)$ and a rising GDP deflator.

3/ For projection, line includes the impact of price and exchange rate changes.

4/ Defined as current account deficit, plus amortization on medium- and long-term debt, plus short-term debt at end of previous period.

5/ The key variables include real GDP growth; nominal interest rate; dollar deflator growth; and both noninterest current account and nondebt inflows in percent of GDP.

6/ Long-run, constant balance that stabilizes the debt ratio assuming that key variables (real GDP growth, nominal interest rate, dollar deflator growth, and nondebt inflows in percent of GDP)

remain at their levels of the last projection year. 
Figure 4. Egypt: External Debt Sustainability: Bound Tests 1/

(External debt in percent of GDP)
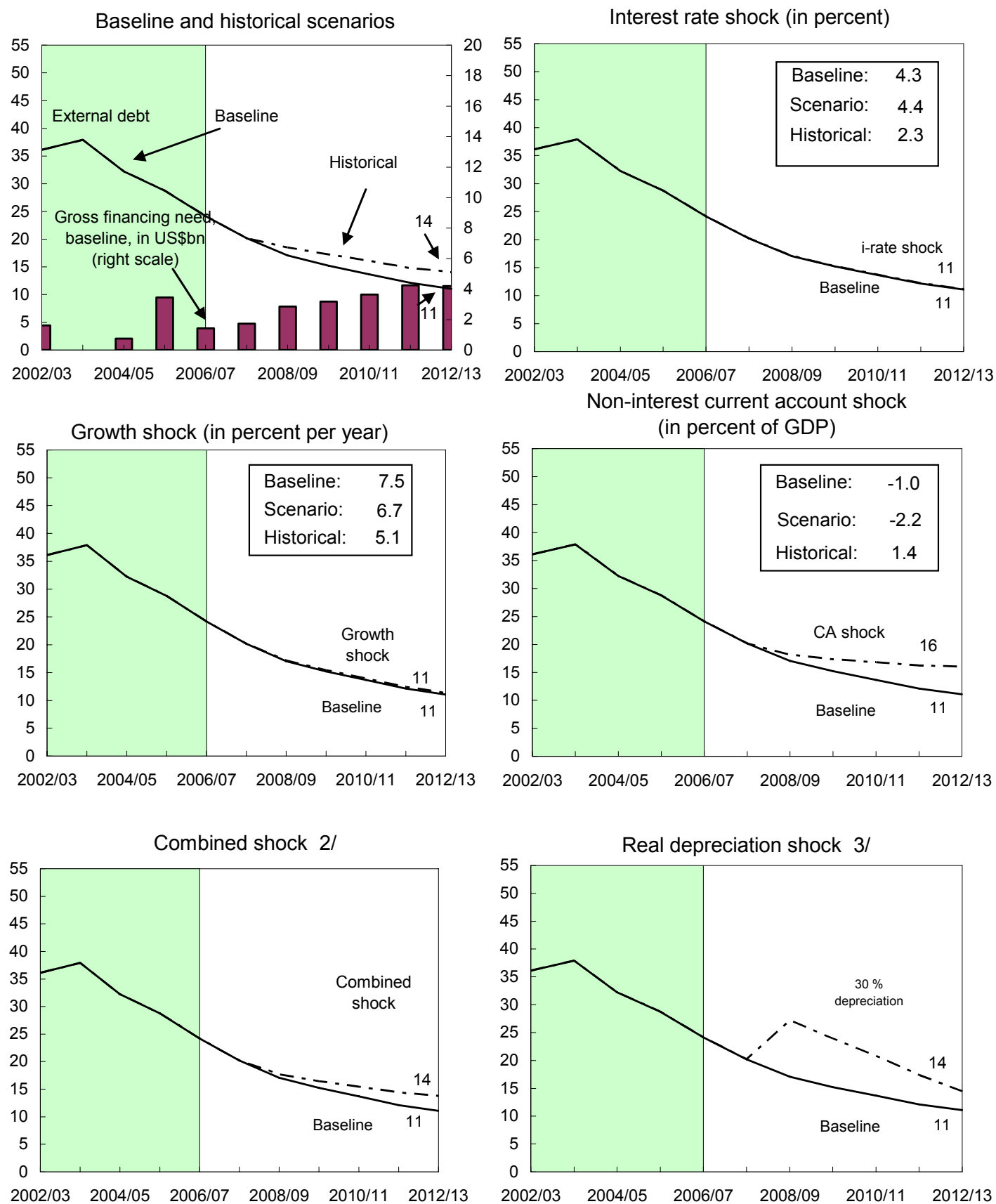

Sources: International Monetary Fund, Country desk data, and staff estimates.

1/ Shaded areas represent actual data. Individual shocks are permanent one-half standard deviation shocks. Figures in the boxes represent average projections for the respective variables in the baseline and scenario being presented. Ten-year historical average for the variable is also shown.

2/ Permanent 1/4 standard deviation shocks applied to real interest rate, growth rate, and current account balance.

$3 /$ One-time real depreciation of 30 percent occurs in 2008/09. 


\section{INTERNATIONAL MONETARY FUND}

\section{ARAB REPUBLIC OF EGYPT}

\section{Article IV Consultation}

\section{Informational Annex}

\section{Prepared by Middle East and Central Asia Department}

(in consultation with other departments)

November 1, 2007

Contents

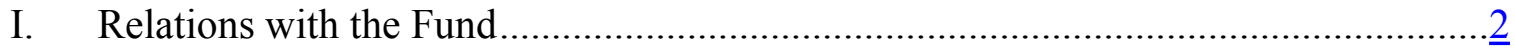

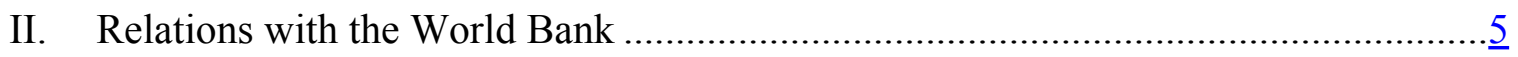

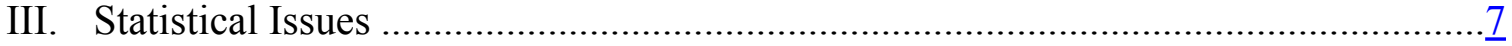




\section{Appendix I. Egypt: Fund Relations}

(As of August 31, 2007)

I. Membership Status: Joined 12/27/45; Article VIII ${ }^{7}$

\section{General Resources Account:}

Quota

Fund holdings of currency $\underline{\text { SDR Million }}$

943.70

943.72
Percent Quota

100.00

100.00

\section{SDR Department:}

Net cumulative allocation

$\underline{\text { SDR Million }}$

135.92

72.71 $\underline{\text { Percent Allocation }}$

100.00

53.49

IV. Outstanding Purchases and Loans: None

V. Financial Agreements:

Type

Approval date
Expiration date
Amount Approved
(SDR million)

Amount Drawn

(SDR million)

Stand-by

EFF

Stand-by
10/11/96

9/20/93

$5 / 17 / 91$
271.40

400.00

234.40
0

0

147.20

VI. Projected Obligations to the Fund: ${ }^{8}$

(SDR million; based on existing use of resources and present holding of SDRs)

\begin{tabular}{llllll} 
& \multicolumn{5}{c}{ Forthcoming } \\
\cline { 2 - 6 } & $\underline{2007}$ & $\underline{2008}$ & $\underline{2009}$ & $\underline{2010}$ & $\underline{2011}$ \\
Charges/interest & 0.51 & 1.99 & 1.99 & 1.99 & 1.99 \\
Total & 0.51 & 1.99 & 1.99 & 1.99 & 1.99
\end{tabular}

\footnotetext{
${ }^{7}$ Egypt accepted the obligations of Article VIII, Sections 2, 3, and 4 on January 2, 2005.

${ }^{8}$ The projection of charges and interest assume that overdue principal at the report date (if any) will remain outstanding, but forthcoming obligations will be settled on time.
} 
VII. Exchange Rate Arrangement (As of October 31, 2007):

Prior to January 29, 2003, the Egyptian pound was pegged to the dollar, with all foreign exchange transactions taking place within $\mathrm{a} \pm 3$ percent range around the central rate, which was announced by the Central Bank of Egypt (CBE). Effective January 29, 2003, the Egyptian pound was allowed to float. As a result, the exchange arrangement of Egypt was reclassified to the category "managed float with no pre-announced path for the exchange rate," from the category "pegged exchange rate within horizontal bands." In December 2004, the CBE officially launched the foreign exchange interbank market with no controls on rates, governed by a formal interbank convention on foreign exchange trading. The CBE stands ready to purchase foreign exchange in the interbank market for banks to the extent they exceed prudential limits on net open positions at the prevailing market rate. Effective February 1, 2005, Egypt's exchange rate was reclassified to a conventional peg from a managed float with no predetermined path for the exchange rate. Since July 2007, the de facto exchange arrangement has been akin to a managed float. Egypt maintains a bilateral payment arrangement with Sudan which has been inoperative since the late 1990s.

\section{Article IV Consultation:}

Consultations with Egypt are on a 12-month cycle. The last Article IV consultation discussions were held in Cairo from April 3-16, 2006. The staff report (CR/06/253) was discussed by the Executive Board on July 5, 2006. The 2006 Article IV report, and PIN were published on July 11, 2006.

\section{Financial Sector Assessment Program (FSAP):}

An FSAP Update mission was conducted in May 2007.

\section{Review of Standards and Codes (ROSC):}

FAD Fiscal module of ROSC

MFD Financial Sector Assessment Program (FSAP)

STA Data ROSC (published on July 21, 2005).
June 2001

October 2002

October 2003 


\section{Technical Assistance (2006-07)}

\begin{tabular}{lll}
\hline Dept. & \multicolumn{1}{c}{ Topic } & \multicolumn{1}{c}{ Date } \\
\hline FAD/ & Revenue administration (first of two visits) & February 2006 \\
METAC & & \\
FAD/LEG & Tax policy-Agricultural land tax & March 2006 \\
MFD & Monetary policy expert (last of seven visits) & March 2006 \\
FAD & Tax administration expert (first of four visits) & May 2006 \\
LEG & Article VIII mission & May 2006 \\
METAC & Balance of Payments and IIP & May, August 2006 \\
MFD & TA Assessment on Monetary Operations (inflation targeting) & June 2006 \\
LEG & Forum for compliance officers on AML/CFT & July 2006 \\
FAD & Cash management expert (first of two visits) & August 2006 \\
FAD & Tax administration expert (second of four visits) & August 2006 \\
STA & IIP statistics seminar & September 2006 \\
STA & Government finance statistics & September 2006 \\
FAD & Revenue administration TA evaluation & September 2006 \\
FAD & Fiscal Reporting & September 2006 \\
METAC & Consumer price statistics & Nov 2006, Feb and \\
& & April 2007 \\
FAD/ & Revenue administration & December 2006 \\
METAC & & \\
FAD & Tax administration & December 2006 \\
FAD & Macrofiscal advisory & December 2006 \\
FAD & Macrofiscal advisory & February 2007 \\
FAD & Tax administration expert (third of four visits) & March 2007 \\
FAD & Cash administration expert (last of two visits) & March 2007 \\
FAD/ & Follow up mission on treasury single account implementation & March 2007 \\
METAC & & \\
LEG & National workshop for insurance supervisor (AML/CBT) & April 2007 \\
FAD & Macrofiscal advisory & June 2007 \\
FAD & Tax administration & July 2007 \\
FAD/ & Treasury single account establishment & August 2007 \\
METAC & & \\
& &
\end{tabular}

\section{Resident Representative:}

Cyrus Sassanpour has been Senior Resident Representative in Cairo since September 2004. 


\section{Appendix II. Egypt: Relations with the World Bank}

\section{Egypt: Relations with the World Bank}

1. Partnership for Development. Key development objectives of the government of Egypt as expressed in its development plan are to achieve high and sustainable growth by enhancing the role of the private sector in the development process; focusing the public sector on delivering public goods; and strengthening the social safety net system. Within the context of a lending program (outlined in the Country Assistance Strategy of FY2002-2004) which was modest in relation to the size and importance of the country, the Bank assisted the Government in addressing its development challenges. During that Country Assistance Strategy period, the Bank and the Government also collaborated on several pieces of analytical work that led to both a better and a shared understanding in such areas as poverty trends, gender achievements and education sector needs. The spirit that marked this collaborative effort bodes well for the future as the shared understanding feeds into policy and project design as well as leads to faster implementation of Bank interventions.

2. World Bank Country Assistance Strategy. The current Bank assistance is anchored in a Country Assistance Strategy (CAS) for the period FY2006-FY2009, which the Bank's Board of Directors endorsed on June 16, 2005. In line with the Government's development and reform agenda, the CAS identified and implements interventions that will facilitate private sector development, enhance the provision of public services, and promote equity.

3. IMF-World Bank Collaboration in Specific Areas. The Bank and IMF continues to collaborate efforts in supporting the Government in the areas of macro-economic framework and management; budget and public expenditure management; public sector reform; and private and financial sector development.

Table 1: Bank-Fund Collaboration in Egypt

\begin{tabular}{|l|l|l|l|}
\hline Area & $\begin{array}{l}\text { Specialized Advice } \\
\text { from Fund }\end{array}$ & $\begin{array}{l}\text { Specialized Advice from } \\
\text { Bank }\end{array}$ & Key Instruments \\
\hline $\begin{array}{l}\text { Economic } \\
\text { Manamework/ }\end{array}$ & $\begin{array}{l}\text { Monetary policy, } \\
\text { exchange rate, fiscal, } \\
\text { and } \\
\text { trade policies, } \\
\text { economic } \\
\text { statistics }\end{array}$ & $\begin{array}{l}\text { Economic growth, } \\
\text { economic statistics }\end{array}$ & $\begin{array}{l}\text { IMF: Article IV } \\
\text { consultations } \\
\text { Bank: Economic work } \\
\text { and technical } \\
\text { assistance }\end{array}$ \\
\hline $\begin{array}{l}\text { Budget and } \\
\text { Public } \\
\text { Expenditure } \\
\text { Management }\end{array}$ & $\begin{array}{l}\text { Medium-term budget } \\
\text { framework, tax policy } \\
\text { and administration, } \\
\text { customs, debt } \\
\text { management, extra } \\
\text { budgetary funds. }\end{array}$ & $\begin{array}{l}\text { Budget management, } \\
\text { debt management and } \\
\text { statistics and public } \\
\text { expenditure management }\end{array}$ & $\begin{array}{l}\text { IMF: Technical } \\
\text { assistance } \\
\text { Bank: Sector work } \\
\text { (PER, CFAA, CPAR) } \\
\text { and technical } \\
\text { assistance }\end{array}$ \\
\hline $\begin{array}{l}\text { Public Sector } \\
\text { Reform }\end{array}$ & \multicolumn{2}{|l|}{$\begin{array}{l}\text { Civil service reform, } \\
\text { anti-corruption agenda, } \\
\text { decentralization. }\end{array}$} & $\begin{array}{l}\text { IMF: Technical } \\
\text { assistance } \\
\text { Bank: Sector work }\end{array}$ \\
\hline $\begin{array}{l}\text { Private and } \\
\text { Financial } \\
\text { Sector } \\
\text { Development }\end{array}$ & Banking supervision & $\begin{array}{l}\text { Investment climate } \\
\text { reforms, financial sector } \\
\text { restructuring, mortgage } \\
\text { market development }\end{array}$ & $\begin{array}{l}\text { IMF: } \\
\text { Bank: Sector work, } \\
\text { technical assistance } \\
\text { and lending }\end{array}$ \\
\hline
\end{tabular}




\section{World Bank/IDA Portfolio}

4. As of September 30, 2007, the Bank approved for Egypt 116 projects valued at about $\$ 6.3$ billion (excluding grants and cancellations) of which about $\$ 5.5$ billion have been disbursed. The current portfolio has 15 active projects with commitment value of about US $\$ 1.3$ billion and an undisbursed balance of about US\$841.5 million. The sectoral composition of these 15 projects (by value) is as follows: 53 percent for infrastructure, 3 percent for financial sector, 28 percent for agriculture, and 16 percent for social sector.

\section{International Finance Corporation (IFC) Investments}

5. As of September 30, 2007, IFC's total committed portfolio was $\$ 409$ million for 34 projects for its own account. The portfolio is diversified and includes investments in the financial sector, power, export-oriented manufacturing, ports, oil and gas, metals, agribusiness, mining, IT, and health care. In FY07, IFC committed US\$310 million in Egypt, more than triple the FY06 commitments of US\$81 million. IFC's investment work in Egypt has been strongly supported by the Public Enterprise Partnership (PEP-MENA) advisory work in the areas of business start-up simplification, SME access to finance and management training, microfinance, corporate governance, and training of women entrepreneurs. Cairo is the regional HQ of IFC's MENA Department and is the hub for IFC's investment activity in eight Middle East countries of the MENA Region.

\section{Multilateral Investment Guarantee Agency (MIGA) Exposures}

6. MIGA's portfolio in Egypt, as a host country, consists of one project, sponsored by a Spanish investor, in the waste management sector. Earlier, there were two claims, filed by the investor with regard to the project, which have since been resolved. The outstanding gross exposure from this investment stands at $\$ 6.4$ million. As an investor country, MIGA is currently sponsoring an Egyptian investor in support of two telecom projects in Pakistan and Bangladesh, with a combined gross exposure of US\$ 152.2 million. As of the first quarter of FY08, MIGA has not received any requests to provide coverage of projects in support of development in Egypt.

Bank Group Activities

As of September 30, 2007

(In millions of U.S. dollars)

\begin{tabular}{|c|c|c|c|}
\hline & IBRD & IDA & TOTAL \\
\hline \multicolumn{4}{|l|}{ IBRD/IDA Lending Operations } \\
\hline Disbursed & 3,762 & 1,787 & 5,549 \\
\hline Undisbursed and committed & 799.9 & 41.6 & 841.5 \\
\hline \multicolumn{4}{|c|}{ Number of closed loans/credits $=101$} \\
\hline \multicolumn{4}{|c|}{ Number of ongoing loans/credits = 15} \\
\hline \multicolumn{4}{|c|}{ Operations Portfolio--Sectoral distribution (less cancellations) } \\
\hline Infrastructure & 694.6 & 0 & 694.6 \\
\hline Financial Sector & 37.1 & 0 & 37.1 \\
\hline Social Sector & 75.5 & 140.0 & 215.5 \\
\hline Agriculture & 335 & 40.0 & 375 \\
\hline Total & 1142.2 & 180 & 1322.2 \\
\hline IFC Investments & & & 512 \\
\hline MIGA gross exposure (inward) & & & 6.4 \\
\hline
\end{tabular}

Source: World Bank Group 


\section{Appendix III. Egypt: Statistical Issues}

1. National accounts. National accounts data are compiled on an annual fiscal year basis and a quarterly basis by the National Accounts Department within the Ministry of Planning in current and constant prices, using the 1993 System of National Accounts (SNA 1993). The data have a number of shortcomings, including inconsistencies with the balance of payments and the absence of a reliable series on GDP and its uses, at constant prices (the base year is often changed without an overlap for the series with different base). Shortcomings in terms of annual and quarterly data timeliness, reliability, and availability weaken the accurate and timely analysis of economic developments. There are discrepancies between quarterly and annual GDP figures. The October 2003 data ROSC mission found that there is scope for improving national accounts statistics, including the need for a more critical review of source statistics. There are no periodic user surveys or an oversight body to provide guidance on the quality of national accounts.

2. $\quad$ Price and labor market statistics. An updated CPI with new weights according to the 1999-2000 household expenditure survey was first published in April 2004. The 2003 ROSC found that various constraints, including computer resources, curtailed much needed innovations in the CPI, and the index may not have been adequately accurate. Price statistics were revised without providing an explanation in August 2005. The Central Agency for Public Mobilization and Statistics (CAPMAS) plans to release a new Consumer Price Index (CPI), referenced to January 2007, in late 2007. The new CPI weights will be based on consumer spending in 2004/2005. It will reflect new methods that include a modified formulation that allows new items to be more easily introduced into the index and aggregation of regional indices based on expenditure, as opposed to population shares. There remains a need to expand the sample of outlets from which prices are collected. The authorities are currently involved in projects to improve the sampling of outlets for the CPI and to complete development of the PPI with technical assistance from METAC in close cooperation with the STA. These actions are complemented by a training program in price statistics to be delivered by the U.S. Bureau of Labor Statistics. There are plans to improve the external trade price indices (the latter are unreliable and available only annually).

3. Balance of Payments (BOP) statistics. BOP statistics are compiled and disseminated by the Central Bank of Egypt (CBE) in accordance with the BMP5. The 2003 data ROSC mission noted that balance of payments statistics face problems with source data. Because merchandise trade statistics based on customs declarations have serious problems, compilers have to rely on banks' foreign exchange records to estimate exports and imports of goods. However, the coverage and classification of foreign exchange transactions are declining following exchange liberalization. Source data do not reasonably approximate accrual basis. Another key shortcoming is the lack of survey data for direct investment enterprises.

4. Foreign Direct Investment. A METAC mission in March 2005 provided technical assistance in measuring foreign direct investment (FDI) to the CBE, the 
Ministry of Investment (MOI), and the General Administration for Investment and Free Zones (GAFI). The METAC expert made several recommendations, including proposing a benchmark FDI survey to collect data on the stocks and flows associated with FDI. Further, based on discussions with the CBE, MOI, GAFI, CAPMAS, the Ministry of Petroleum, the Capital Market Authority, and the American Chamber of Commerce, recommendations were made to the $\mathrm{CBE}$ to revise the balance of payments data related to direct investment, services receipts, income payments, other foreign investments in Egypt, and other sectors' assets abroad. These recommendations were consistent with the ROSC recommendations. Subsequently, the CBE incorporated petroleum investment data into the balance of payments for the third and fourth quarters of 2004 and first quarter of 2005 .

5. In 2006 two METAC missions provided further technical assistance on the compilation of FDI statistics, particularly in survey design, sampling, and constructing a business register. In consultation with the Joint Committee on FDI statistics, a work plan was drawn up. A subsequent METAC mission on FDI is planned for the fall of 2007 , depending on the progress made by the authorities.

6. External debt and the international investment position (IIP). In September 2006 STA provided a seminar on IIP statistics and workshop sessions were held with the compilers to prepare IIP in the required international format for publication by STA (IIP data for Egypt are now disseminated through the IFS and BOPSY). The mission identified gaps in the data and inconsistencies between flows and stock data and the authorities agreed to work on closing the gaps, to the extent possible. The mission also encouraged the authorities to submit the reserves template to STA for posting on the Fund's external website and consultations are ongoing through the Senior Resident Representative.

7. Data on external debt meets SDDS requirements. The authorities are drawing on advice from Fund staff and other outside advisers to design a strategy for strengthening the reporting system on non-guaranteed debt.

8. Fiscal data. The authorities are in the process of adopting a new budget classification (NBC) based on the GFSM 2001, with FAD and STA advice, and several of the requirements of the GFSM 2001 have already been met. Nonetheless, the consolidation of general government operations (budget sector, National Investment Bank, and Social Insurance Funds) under this new classification has not been finalized, and has been fully applied only to "above-the-line" transactions. Annual data were recently reported using the GFSM 2001 methodology-on a cash-basis-for the Government Finance Statistics (GFS) Yearbook for the fiscal years 2003-2007. No data are reported for publication in the International Financial Statistics (IFS). The presentation of the fiscal data used to meet the SDDS requirements for general government operations and central government operations-on a cash basis-largely conforms to the GFSM 2001 methodology (see Egypt's National Summary Data Page at http://www.mop.gov.eg/MOP_META/nsdp.htm). 
9. Monetary statistics. The statistics are comprehensive and reported regularly. The data ROSC for Egypt raised the issue of potential overstatement of foreign assets and foreign liabilities of the banking sector, as recorded in the monetary statistics, because an offshore bank located in Egypt is erroneously treated as a nonresident entity. Egypt is reporting monetary data to STA using the Standardized Report Forms.

10. Data dissemination. Egypt subscribed to the SDDS in January 2005. Remaining issues include the timeliness of the labor market data on employment and unemployment, and the timeliness and periodicity of the labor market data for wages/earnings and data for central government operations.

11. Data ROSC. A data ROSC report, based on an October 2003 mission, assessing the quality of Egypt's macroeconomic statistics and recommending improvements was published in July 2005. 


\section{EGYPT: TABLE OF COMMON INDICATORS REQUIRED FOR SURVEILLANCE}

(As of October 11, 2007)

\begin{tabular}{|c|c|c|c|c|c|c|c|}
\hline & \multirow{2}{*}{$\begin{array}{c}\text { Date of } \\
\text { latest } \\
\text { observation }\end{array}$} & \multirow{2}{*}{$\begin{array}{l}\text { Date } \\
\text { received }\end{array}$} & \multirow{2}{*}{$\begin{array}{c}\text { Frequenc } \\
\text { y of } \\
\text { Data }^{6}\end{array}$} & \multirow{2}{*}{$\begin{array}{l}\text { Frequenc } \\
\text { y of } \\
\text { Reporting } \\
\quad 6\end{array}$} & \multirow{2}{*}{$\begin{array}{l}\text { Frequenc } \\
\text { y of } \\
\text { Publicatio } \\
n^{6}\end{array}$} & \multicolumn{2}{|c|}{ Memo Items: } \\
\hline & & & & & & $\begin{array}{l}\text { Data Quality - } \\
\text { Methodologica } \\
\text { I soundness } 7\end{array}$ & $\begin{array}{l}\text { Data Quality - } \\
\text { Accuracy and } \\
\text { reliability }^{8}\end{array}$ \\
\hline Exchange Rates & real time & real time & $\mathrm{D}$ & $\mathrm{D}$ & $\mathrm{D}$ & & \\
\hline $\begin{array}{l}\text { International Reserve Assets and Reserve } \\
\text { Liabilities of the Monetary Authorities }{ }^{1}\end{array}$ & Jun-07 & Sept-07 & M & M & M & & \\
\hline Reserve/Base Money & May-07 & Aug-07 & M & M & M & O,O,LO,LO & $\mathrm{O}, \mathrm{O}, \mathrm{O}, \mathrm{O}, \mathrm{O}$ \\
\hline Broad Money & May-07 & Aug-07 & M & M & M & & \\
\hline Central Bank Balance Sheet & May-07 & Aug-07 & M & M & M & & \\
\hline $\begin{array}{l}\text { Consolidated Balance Sheet of the Banking } \\
\text { System }\end{array}$ & May-07 & Aug-07 & M & M & M & & \\
\hline Interest Rates ${ }^{2}$ & real time & real time & $\mathrm{D}$ & $\mathrm{D}$ & $\mathrm{D} / \mathrm{l}$ & & \\
\hline Consumer Price Index & Aug-07 & Sept-07 & M & M & M & $\mathrm{O}, \mathrm{O}, \mathrm{O}, \mathrm{O}$ & $\begin{array}{l}\text { LNO,LNO,LN, } \\
\text { LO,LO }\end{array}$ \\
\hline $\begin{array}{l}\text { Revenue, Expenditure, Balance and } \\
\text { Composition of Financing }{ }^{3}-\text { General } \\
\text { Government }\end{array}$ & $\begin{array}{l}\text { Q4 2006/ } \\
07\end{array}$ & Sep-07 & I & I & $Q / I$ & LO,LO,O,O & $\mathrm{LO}, \mathrm{O}, \mathrm{O}, \mathrm{O}, \mathrm{O}$ \\
\hline $\begin{array}{l}\text { Revenue, Expenditure, Balance and } \\
\text { Composition of Financing }{ }^{3}-\text { Central } \\
\text { Government }\end{array}$ & $\begin{array}{l}\text { Q4 2006/ } \\
07\end{array}$ & Sep-07 & I & I & $\mathrm{Q} / \mathrm{I}$ & & \\
\hline $\begin{array}{l}\text { Stocks of Central Government and Central } \\
\text { Government-Guaranteed Debt }\end{array}$ & Jun-07 & Sep-07 & I & 1 & $A / Q$ & & \\
\hline External Current Account Balance & $\begin{array}{l}\text { Q4 2006/ } \\
07\end{array}$ & Sep-07 & I & I & Q & O,LO,LO,LO & $\mathrm{LNO}, \mathrm{O}, \mathrm{O}, \mathrm{O}, \mathrm{O}$ \\
\hline Exports and Imports of Goods and Services & $\begin{array}{l}\text { Q4 2006/ } \\
07\end{array}$ & Sep-07 & I & I & Q & & \\
\hline GDP/GNP & $\begin{array}{l}\text { Q4 2006/ } \\
\quad 07\end{array}$ & Sep-07 & Q & Q & Q & $\mathrm{O}, \mathrm{O}, \mathrm{O}, \mathrm{LO}$ & $\begin{array}{l}\text { LO,LO,LO,O, } \\
\text { LO }\end{array}$ \\
\hline Gross External Debt & $\begin{array}{l}\text { Q4 2006/ } \\
07\end{array}$ & Sep-07 & I & I & Q & & \\
\hline
\end{tabular}

${ }^{1}$ Includes reserve assets pledged or otherwise encumbered as well as net derivative positions.

${ }^{2}$ Both market-based and officially-determined, including discount rates, money market rates, rates on treasury bills, notes and bonds.

${ }^{3}$ Foreign, domestic bank, and domestic nonbank financing.

${ }^{4}$ The general government consists of the central government (budgetary funds, extra budgetary funds, and social security funds) and state and local governments.

${ }^{5}$ Including currency and maturity composition.

${ }^{6}$ Daily (D); weekly (W); monthly (M); quarterly (Q); annually (A); irregular (I); and not available (NA).

${ }^{7}$ Reflects the assessment provided in the data ROSC (published on July 11, 2005, and based on the findings of the mission that took place during October 7-

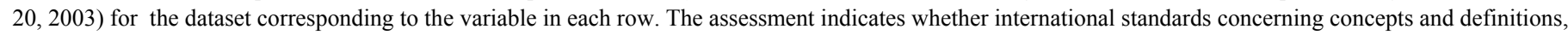

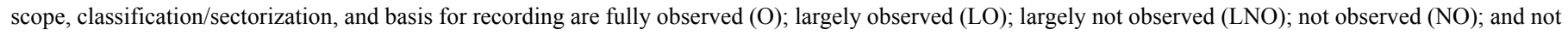
available (NA).

${ }^{8}$ Same as footnote 7 , except referring to international standards concerning source data, statistical techniques, assessment and validation of source data, assessment, and revision studies. 


\section{Egypt: Work Program}

Staff Visit

March/April 2008 (tentative)

Article IV Consultation

Article IV Consultation mission

October/November 2008 (tentative) 


\section{Statement by the IMF Staff Representative November 28, 2007}

1. The following information has become available since the issuance of the staff report on November 2, 2007. It does not alter the thrust of the staff appraisal.

2. Inflation — as measured by the old CPI — moderated to 6.9 percent in October (yearon-year basis) after rising slightly in September to 8.8 percent. Since September, the authorities have also published a new CPI series with updated weights of the consumption basket. This series covers observations available since January 2007 and involves a greater weight of food in the basket (a revision in weight from 39 to 44 percent). Under the new series, monthly CPI inflation in September and October was 2.1 percent and 1.0 percent, respectively (compared to 1.4 percent and 0.9 percent under the old series).

3. Balance of payments data for the July-September 2007 period show a somewhat larger deterioration in the current account (by US\$1.5 billion, compared to July-September 2006) than projected by staff (US\$1 billion), largely because of higher than anticipated service payments for transportation and travel. Non-oil exports expanded by 20 percent, but oil exports fell sharply. The decline in the current account balance was more than offset by higher FDI inflows, including in the oil sector.

4. The growth of monetary aggregates moderated somewhat, reflecting some capital outflow in September-following the global credit crunch - and stepped-up sterilization in October. The year-on-year increase in reserve money decelerated to 14 percent in October (from 18 percent in September), while broad money growth in September was 17 percent (down from 18 percent in August).

5. The authorities have issued a government decree raising gas and electricity prices for large industrial consumers (except those in the food processing and textiles industries). Gas prices will more than double and electricity prices will increase by about 60 percent over a three year period. Preliminary estimates indicate that these measures could yield over 1 percent of GDP in annual savings by $2009 / 10$.

6. Preliminary fiscal data for the first quarter of fiscal year 2007/08 suggest buoyant revenues after adjusting for one-off factors, and expenditure growth broadly in line with seasonal patterns. The recently enacted energy price adjustment for industrial users should help reach this year's budget target. 
Public Information Notice (PIN) No. 07/139

FOR IMMEDIATE RELEASE

December 3, 2007
International Monetary Fund

$70019^{\text {th }}$ Street, NW

Washington, D. C. 20431 USA

\section{IMF Executive Board Concludes 2007 Article IV Consultation with the Arab Republic of Egypt}

On November 28, 2007, the Executive Board of the International Monetary Fund (IMF) concluded the Article IV consultation with the Arab Republic of Egypt. ${ }^{9}$

\section{Background}

Sustained and bold reforms, prudent macroeconomic management, and a favorable external environment enabled the Egyptian economy to register another year of impressive performance. Growth remained high and has become more broad-based, creating record numbers of jobs. Inflation has returned to single digits after spiking during the year through March 2007. Investor confidence remains high.

Real GDP growth in 2006/07 is estimated at 7.1 percent, the highest in years. The expansion was broad-based, with a further acceleration in non-hydrocarbon sectors, including in agriculture and manufacturing. The growth since end-2004 has added 2.4 million jobs as of end-March 2007, reducing unemployment from 10.5 percent to 9 percent.

Strong growth and rising equity and real estate prices have boosted domestic demand, contributing to strong import growth and a pick-up in underlying inflation. Exports also rose sharply, along with worker remittances, Suez canal receipts, and tourism revenues. With record levels of FDI, the balance of payments recorded a surplus of US $\$ 5.3$ billion in 2006/07, bringing official reserves to the equivalent of more than 6 months of imports of goods and services. A spike in inflation over the year through March 2007 was driven largely by the impact of an avian flu outbreak and adjustments in administered fuel prices in 2006;

\footnotetext{
${ }^{9}$ Under Article IV of the IMF's Articles of Agreement, the IMF holds bilateral discussions with members, usually every year. A staff team visits the country, collects economic and financial information, and discusses with officials the country's economic developments and policies. On return to headquarters, the staff prepares a report, which forms the basis for discussion by the Executive Board. At the conclusion of the discussion, the Managing Director, as Chairman of the Board, summarizes the views of Executive Directors, and this summary is transmitted to the country's authorities.
}

Washington, D.C. 20431 • Telephone 202-623-7100 • Fax 202-623-6772 • www.imf.org 
but a rise in underlying inflation (one that excludes food and most energy prices) points to some spillovers and demand pressures as well, along with some imported inflation. After peaking at 12.8 percent in March 2007, CPI inflation has gradually receded since, to 8.5 percent in August; underlying inflation has also fallen substantially.

Macroeconomic policies in 2006/07 helped contain demand and inflationary pressures, but were complicated by strong capital inflows. Monetary policy was tightened once spillover effects of administered price increases became visible, and the nominal exchange rate allowed to appreciate by 1.1 percent against the U.S. dollar in the year to end-June, with considerably greater flexibility since then. Through the partial sterilization of external inflows, broad money growth was kept in the 13-15 percent range until April 2007, but subsequently surged to 18 percent.

Fiscal imbalances narrowed as there was significant underlying adjustment in 2006/07. Preliminary data indicate a central government deficit of 7.5 percent of GDP, below the 9 percent average of recent years, largely due to structural improvements in the tax area, fuel price adjustments, wage restraint, and windfall receipts from a telecom license sale, with a broadly similar adjustment for the general government (which includes social security funds and the National Investment Bank, NIB). Combined with privatization receipts and the draw-down of idle cash balances following the consolidation of most government accounts into a Treasury Single Account (TSA), budget borrowing requirements fell dramatically, contributing to a decline in T-bill yields.

Structural reforms advanced significantly in promoting a private sector driven economy. The fourth largest state bank (Bank of Alexandria) and a large department store chain along with other assets were sold to foreign investors (about 1.4 percent of GDP). Import tariffs were reduced in early 2007, and tax administration reforms progressed. Cash and debt management was streamlined by consolidating government accounts into a treasury single account and by the settlement of circular debts among the central government, the NIB and the Social Insurance Funds. Plans are afoot to restructure the pension system with assistance from the World Bank and the government is putting in place a strong institutional framework for PPPs. Egypt successfully issued its first international local-currency bond (LE 6 billion), seeking to widen the investor pool, foster secondary trading and hence establish a meaningful benchmark yield curve.

Recent steps undertaken to facilitate business activities include slashing the time, fees, and minimum capital required to set up a business; drastically lowering fees for registering property; and cutting further the time needed for imports and exports to clear customs.

Egypt's macroeconomic vulnerabilities seem low. The diversified sources of foreign capital (mostly from Europe, the GCC countries and North America) and a still-low share of speculative funds limit the risk of a sudden reversal of capital flows. The vulnerability to any reversal is furthermore limited as little of these inflows have been intermediated through the banking system and the CBE's international reserves are high. Stress testing conducted during the recent joint World Bank/IMF Financial Sector Assessment Program (FSAP) Update highlights that the banking system would be vulnerable mainly to a deterioration of 
domestic credit quality and much less to exchange and interest rate movements. To date Egypt has weathered the recent turbulences in global financial markets rather well, some pullback in the stock and fixed-income markets notwithstanding.

\section{Executive Board Assessment}

Executive Directors commended the Egyptian authorities' sound macroeconomic management and bold economic reforms. Fiscal adjustment and significant achievements in privatization and financial sector reform have increased market confidence and boosted investment, thereby helping to sustain a high pace of economic growth. Growth is increasingly broad-based, contributing to a substantial reduction in unemployment.

Looking ahead, Directors observed that important challenges remain. They pointed, in particular, to the high government budget deficit, shallow financial intermediation, and remaining bureaucratic barriers to private sector activity. Furthermore, domestic demand continues to contribute to the inflationary pressures. Directors also cautioned that the slow trickle-down of the benefits of economic growth could weaken public support for the reform effort.

Against this background, Directors welcomed the authorities' commitment to reduce the fiscal deficit to 3 percent of GDP by fiscal year 2010/11. This will help further increase investor confidence, further improve the economy's resilience to exogenous shocks, reduce the public debt, and underpin macroeconomic stability. In this context, Directors commended the fiscal adjustment achieved last year, including through the reform of tax administration and public finance management and the reduction of fuel subsidies. They welcomed the planned further reduction of fuel subsidies, and called for stronger social safety nets to protect vulnerable segments of the population, as well as more efficient and better prioritized social spending. Directors looked forward to quick progress on the value added tax reform, containment of the wage bill, and further broadening of the tax base.

Directors commended the efforts of the central bank to strengthen monetary policy formulation and improve the interest rate transmission mechanism. They generally supported the central bank's pragmatic approach of focusing on underlying inflation to forestall second-round effects of administered price increases and supply shocks. Directors cautioned that, going forward, monetary policy will need to be vigilant in light of continued demand pressures. They welcomed the planned adoption of inflation targeting, which should be introduced after steps are taken to ensure a competitive banking system and a consistent monetary policy framework.

Directors welcomed the move to greater exchange rate flexibility since mid-2007, which has enhanced the coherence of the macroeconomic policy mix. The ensuing exchange rate appreciation has helped in curbing inflation. Directors considered that allowing a greater role for market forces in determining the exchange rate would help to deal with pressures arising from capital inflows and to underpin the move to inflation targeting. They agreed that Egypt's current account is consistent with external stability, and that the exchange rate is broadly in line with economic fundamentals. 
Directors commended the significant progress in financial sector reform, and welcomed the authorities' plans for further reform in line with key recommendations of the recent FSAP update. They welcomed the successful sale of a major state-owned bank and the efforts to reduce the nonperforming loans in the banking system. They encouraged completion of the privatization of another bank in 2008 as planned. Directors emphasized the importance of improving supervision, completing bank recapitalization, enhancing the monitoring of state banks, and undertaking complementary regulatory and judicial reforms. Some Directors called for gradual privatization of the large state-owned insurance company, in line with the authorities' overall thrust toward greater private sector participation in the financial sector.

Directors stressed that enhancing the investment climate will be crucial to sustain the growth momentum. They welcomed the ongoing efforts to reduce barriers to private sector activity, including through lower import tariffs, reduction of red tape, and a strengthened legal framework for business activities. They also pointed out that a faster pace of job creation will require labor market reforms and education to reduce skill mismatches, non-wage costs, and constraints on hiring and firing.

Public Information Notices (PINs) form part of the IMF's efforts to promote transparency of the IMF's views and analysis of economic developments and policies. With the consent of the country (or countries) concerned, PINs are issued after Executive Board discussions of Article IV consultations with member countries, of its surveillance of developments at the regional level, of post-program monitoring, and of ex post assessments of member countries with longer-term program engagements. PINs are also issued after Executive Board discussions of general policy matters, unless otherwise decided by the Executive Board in a particular case. 
Egypt: Selected Economic Indicators 1/

\begin{tabular}{|c|c|c|c|c|c|}
\hline & & & & Est. & Proj \\
\hline & $2003 / 04$ & $2004 / 05$ & $2005 / 06$ & $2006 / 07$ & $2007 / 08$ \\
\hline \multicolumn{6}{|l|}{ Real Sector } \\
\hline Real GDP growth & 4.1 & 4.5 & 6.8 & 7.1 & 7.3 \\
\hline CPI inflation (average) & 8.1 & 8.8 & 4.2 & 10.9 & 7.8 \\
\hline Unemployment rate (in percent) & 11.1 & 10.5 & 10.9 & 9.0 & $\ldots$ \\
\hline \multicolumn{6}{|l|}{ Public Finances } \\
\hline Balance of the general government (in percent of GDP) & -8.3 & -8.4 & -9.2 & -7.7 & -6.9 \\
\hline Net public debt (in percent of GDP) & 82.4 & 80.5 & 79.8 & 72.6 & 69.4 \\
\hline \multicolumn{6}{|l|}{ Money and credit } \\
\hline Broad money growth (annual rate) & 13.2 & 13.6 & 13.5 & 18.3 & 16.8 \\
\hline Credit to the private sector (annual growth rate) & 4.5 & 3.6 & 8.6 & 12.3 & 12.8 \\
\hline Interest rates on 91-day treasury bills (in percent) & 8.4 & 10.2 & 8.8 & 8.7 & $\ldots$ \\
\hline \multicolumn{6}{|l|}{ External Sector } \\
\hline Trade balance (in percent of GDP) & -9.9 & -11.5 & -11.2 & -12.4 & -13.0 \\
\hline Current account balance (in percent of GDP) & 4.3 & 3.2 & 0.8 & 1.4 & 0.8 \\
\hline Gross official reserves (in billions of U.S. dollars) & 14.8 & 19.3 & 22.9 & 28.3 & 34.2 \\
\hline (in months of imports of goods and services) & 5.7 & 5.8 & 5.9 & 6.1 & 6.6 \\
\hline Total external debt (in percent of GDP) & 37.9 & 32.2 & 28.8 & 24.2 & 20.2 \\
\hline \multicolumn{6}{|l|}{ Exchange rates } \\
\hline Egyptian pounds per U.S. dollar (average) & 6.2 & 6.0 & 5.8 & 5.7 & $\ldots$ \\
\hline Real effective exchange rate (average; percent change) & -21.6 & 4.2 & 8.1 & 4.4 & \\
\hline
\end{tabular}

Sources: Egyptian authorities; and IMF staff estimates.

1/ Egyptian fiscal year ends June 30.

CInternational Monetary Fund. Not for Redistribution 


\section{Statement by A. Shakour Shaalan, Executive Director for the Arab Republic of Egypt November 28, 2007}

\section{Recent Developments}

1. On recent occasions in Board discussions of Egypt's Article IV consultations, I have emphasized the authorities' commitment to the bold and comprehensive set of economic reforms which were introduced in mid-2004. The momentum of these far-reaching economic reforms has continued well into 2007 , and its dividends, as was the case last year, continue to pay off. The pace of the fiscal consolidation agenda has been adhered to, underpinned by important fuel subsidy and tax administration reforms. Structural reforms accelerated, with the privatization of Egypt's fourth largest bank and a large department store, further reductions in tariff rates, and important measures to improve the business climate and stimulate private sector activity. The monetary policy framework continues to be strengthened, building up toward an inflation targeting regime in the medium term. Progress on key prerequisites for inflation targeting has allowed the introduction of greater exchange rate flexibility since mid-2007, consistent with the authorities' managed float exchange regime, which I should add is not a pegged rate as inadvertently implied by the staff in paragraph 9 of the staff report. They would have been right if they were referring to the past.

2. Against this background, growth surged in 2005/06 and accelerated further in 2006/07 to over 7 percent, driven by a significant expansion of non-oil activity, and generating close to 2.5 million jobs since end-2004. As has been the case in other dynamic economies, inflation picked up somewhat in $2006 / 07$, but is projected to ease significantly as the pressures from exogenous supply shocks and fuel price increases dissipate. The expansion was supported by a strong external sector, as non-oil exports picked up appreciably, FDI flows registered record peaks, mostly in greenfield investments, and the reserve position strengthened further to US $\$ 31$ billion in October 2007. Building on strengthened investor sentiment and several ratings upgrades, Egypt's first international local-currency bond in the amount of LE 6 billion was very well received by the market, setting an encouraging benchmark for a second issuance that is currently being contemplated. I should mention two important pieces of statistics that attest to Egypt's radically improved economic environment. As shown in Table 1 of the staff report, gross national savings increased by about 2.5 percent in the four years to $2007 / 08$ and for the same period capital investment increased by over 6 percent, setting the pace for a brighter outlook.

\section{Outlook and Policies}

3. The authorities share staff's assessment regarding the strength of the medium-term outlook. The range of economic reforms initiated since mid-2004 have significantly improved the economy's fundamentals and enhanced its resilience to external shocks. External vulnerability is further mitigated by the country's net creditor position, with foreign assets of the central bank and commercial banking sector well in excess of the external debt stock and about nine times short-term debt. 
4. In addition to focusing on a reduction in price pressures, the authorities are cognizant that a main challenge in the period ahead is to preserve the momentum of the reforms in the face of broader disenchantment at the delays in the trickle-down of their benefits. Arguably, the limited trickle-down of the reforms is not unusual, given that the current expansion is driven essentially by growing financial integration, which tends to increase inequality by increasing the premium on higher skills. Trickle-down would, therefore, have to be induced through a set of well-designed measures aimed at unleashing the benefits of the reforms. To this end, the authorities are committed to pursuing policies that would enhance the reach and delivery of public social services, while at the same time persevering with the reform agenda to safeguard macroeconomic stability. Going forward, the reform agenda will continue to focus on reinforcing the foundations for a stronger expansion, through further fiscal consolidation to remove distortions in the economy, second-generation financial sector reforms to enhance and deepen financial intermediation and access to credit, and structural reforms to strengthen the business climate in support of higher investment.

\section{Fiscal Policy and Reforms}

5. Fiscal consolidation remains a key pillar of the reform program, with the objective of bringing the deficit down to 3 percent by 2011 being guided by a range of well-identified measures that are progressively being phased in. In line with this objective, the overall deficit for the general government declined by 1.5 percent of GDP in 2006/07. These outturns are consistent with an even larger adjustment in the underlying balance (excluding one-off factors on both the revenue and expenditure sides), which improved by close to 2.7 percent of GDP in 2006/07 to 8.7 percent. The adjustment was essentially expenditure-based, reflecting a reduction in the fuel subsidy bill and wage restraint.

6. In the period ahead, the authorities recognize the importance of maintaining a tightening fiscal stance to remain supportive of monetary policy in containing demand pressures and dealing with the implications of high capital inflows. The 2007/08 budget appropriately envisages a further underlying budget adjustment of 1 percent of GDP to bring the overall deficit down to 7.4 percent, through a balance of revenue-enhancing and expenditure-reducing measures. On the revenue side, measures will focus on improved collections from tax administration reforms. Importantly, laws on reforming the sales tax to a full-fledged VAT will be presented during the current parliamentary session, with implementation expected during the latter half of 2008. The envisaged VAT will carry a unified rate, apply to a broader range of services, and increase the exemption threshold, thereby enhancing buoyancy of the tax system. On the expenditure side, in addition to a partial hiring freeze that is projected to further contain the drift in the wage bill, a decree has been issued in September 2007 which rendered effective the phasing out over a three- to five-year period of gas and electricity subsidies to energy-intensive industries. An important element driving expenditure consolidation going forward is a reduced interest bill in the context of lower budget deficits and financing needs. 


\section{Monetary and Exchange Rate Policies}

7. Monetary policy has been focused on price stability and not the level of the exchange rate, with the Central Bank of Egypt (CBE) broadly targeting underlying inflation while taking into account monetary aggregates and other indicators. In an attempt to rein in inflation, the CBE raised its policy rates (the overnight lending and deposit facility rates) by 50 basis points in November 2006 and a further 25 basis points in December 2006 to 10.75 percent and 8.75 percent respectively. Policy rates have remained unchanged since, reflecting easing pressures on both headline and core inflation as the base effect from the price increases related to earlier supply shocks leveled off. Going forward, and with continued gradual subsidy reduction envisaged under the fiscal adjustment program, the authorities' policies will focus on accommodating one-off effects from administered price adjustments while aiming to contain second-round effects on other prices. Underlying inflation will be kept within the single digits, and the monetary stance will remain vigilant consistent with this objective.

8. The authorities agree with staff's assessment that the exchange rate is broadly in line with fundamentals. They further welcome the convergence of views with staff that the exchange rate regime is a managed float. The recent increased exchange rate flexibility was introduced against the background of progress on key institutional prerequisites for inflation targeting. These include a highly liquid foreign exchange market, improved ability to manage foreign exchange risk, and enhanced institutional and technical capacity to adopt a credible alternative nominal anchor. These developments reflect a range of initiatives introduced to improve the monetary policy framework and support a more effective exchange rate management. Together with recent efforts at establishing a meaningful yield curve through global bond issuances at progressively longer maturities, the establishment of the interest rate corridor has been effective in significantly reducing interest volatility and guiding market expectations. This is paving the way for a more pronounced transmission channel for interest rates going forward, as suggested in the Selected Issues paper. Moreover, predictability and transparency of monetary policy have been enhanced, with the conclusions of the Monetary Policy Committee, which meets every six weeks to set benchmark policy rates, being closely scrutinized and guiding expectations of both domestic and international investors.

9. For this purpose, the CBE has increased its placements of the large balance of payments surpluses with commercial banks, in an effort to provide foreign exchange liquidity to the system and strengthen the financial system's creditworthiness. This strategy has also helped limit the CBE's sterilization needs. From this perspective, the authorities see limited risk stemming from a surge in dollar-denominated bank credits, given that these deposits are invested in very short-term instruments to preserve the liquidity feature of reserves. The strengthened reserve position - part of which was on a one-off basis - was in part directed at building a buffer to guard against the possibility of sudden outflows thereby increasing the resiliency of the economy. Nonetheless, they will closely monitor commercial banks' use of the CBE's placements of foreign exchange. 


\section{Financial Sector Reforms}

10. The Financial Sector Reform Program implemented since 2005 is transforming the financial landscape in Egypt. Progress is on track on key elements of the reform program. In particular, the privatization of Bank of Alexandria has been successfully completed, with further ongoing action to privatize Banque du Caire, Egypt's third largest bank, by mid-2008. Together with large scale divestitures of state ownership in several banks, the majority of banking assets is now held by the private sector. Decisive efforts have been made to clean up banks' balance sheets and settle non-performing loans (NPLs). Delinquencies by state-owned enterprises have been significantly reduced and will be fully settled by end-2007 through cash injections, sales of their investments, and settlements with private creditors. This should appreciably bring down the ratio of NPLs. In addition, a comprehensive plan is being implemented to strengthen bank regulation and supervision and align it with international best practice by end-2008. Finally, the establishment of a private sector credit bureau, regulated and supervised by the $\mathrm{CBE}$, should help overcome some of institutional impediments to bank lending stemming from the credit excesses of the late 1990s and facilitate access to credit by the private sector.

11. The non-banking sector has also witnessed equally important achievements. In the insurance sector, three state insurers were merged into a holding company with the objective of restructuring their financial and operational profiles for eventual privatization. In addition, a new pension law has been drafted that overhauls the existing pension scheme completely. The new scheme is based on a four pillar system comprising a basic pension, a notional defined contribution account system, a fully funded component, and a voluntary additional pillar. Moreover, and while still relatively small, the Egyptian stock market has been expanding steadily, posting one of the best performances in the region. A small cap exchange, NILEX, was also launched in October 2007, to encourage equity financing for small- and medium-sized companies.

12. The authorities are in broad agreement with the recommendations of the Financial System Stability Assessment Update (FSSA). They recognize the developmental and forward-looking character of the assessment, given that many of the recommendations constitute elements of the ongoing reform agenda (2005-08). They take note of the findings that the banking sector is resilient to exchange rate and interest rate shocks, albeit more vulnerable to a deterioration in credit quality. While underscoring the depth and breadth of the restructuring that the banking sector is currently undergoing, the authorities recognize the importance of enhancing the quality of banks' asset classification. Efforts to this end are ongoing, as part of the broader objective of setting up an internal stress testing unit at the CBE. Moreover, the authorities are aware of the potential conflict of interest associated with the transitional arrangements during the reform process. Such arrangement was intentional in view of requirements of the reform plan, and will be discontinued upon completion of the reforms. 


\section{Other Structural Reforms}

13. In an effort to stimulate investment and private sector activity, the government has also stepped up its privatization agenda, along with reforms to improve the business climate and reduce red-tape. In this context, a total of 53 acquisitions and joint venture sale operations were concluded in 2006/07, yielding close to LE14 billion in privatization proceeds. In July 2007, a Declaration on International Investment and Multinational Enterprises of the OECD was signed, setting a new stage for attracting foreign investments and making Egypt the first Arab and African country to sign such declaration. Notably, Egypt was judged to be the top reformer for 2006/07 according to the World Bank Doing Business Report. Deep reforms were reflected in improvements along five key indicators: starting a business, dealing with licenses, registering property, access to credit, and new onestop shops for traders at ports that considerably slashed the time for import and export transits. In addition, and to address the delay characterizing civil and commercial procedures in Egypt, an Economic Courts Bill will be submitted to parliament by end-2007 to establish courts with specialization in commercial matters.

14. Finally, the Egyptian authorities are committed to the vigorous pursuit of their reform agenda to achieve a structurally higher growth rate. They would like to express their appreciation for the extensive and highly valuable technical assistance they are receiving from the Fund in support of their reform efforts, and thank staff for a productive consultation and the reasonably balanced set of reports. They look forward to continued close collaboration with the Fund in the period ahead. 